Portland State University

PDXScholar

$11-22-1976$

\title{
Theoretical Differences in Kissinger and Schlesinger's Models of the International System
}

Wayne Alan Schroeder

Portland State University

Follow this and additional works at: https://pdxscholar.library.pdx.edu/open_access_etds

Part of the International Relations Commons

Let us know how access to this document benefits you.

\section{Recommended Citation}

Schroeder, Wayne Alan, "Theoretical Differences in Kissinger and Schlesinger's Models of the International System" (1976). Dissertations and Theses. Paper 2418.

https://doi.org/10.15760/etd.2415

This Thesis is brought to you for free and open access. It has been accepted for inclusion in Dissertations and Theses by an authorized administrator of PDXScholar. Please contact us if we can make this document more accessible: pdxscholar@pdx.edu. 
AN ABSTRACT OF THE THESIS OF Wayne Alan Schroeder for the degree of Master of Arts in Political Science, presented November 22, 1976

TITLE: THEORETICAL DIFFERENCES IN KISSINGER AND SCHLESINGER'S MODELS OF THE INTERNATIONAL SYSTEM

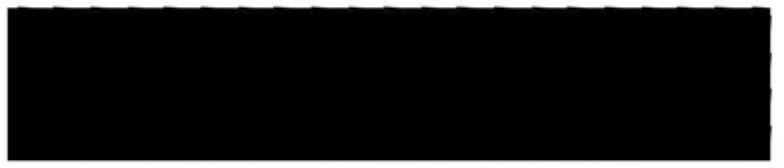

Ladis K. D. Kristof, Chairman
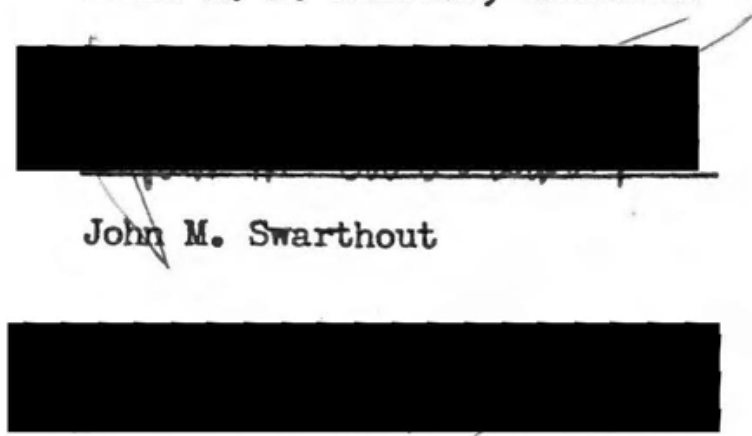

Charles R. White

This thesis is a study of national security decision making in the Ford Administration. The subject for study is the KissingerSchlesinger controversy in the Ford Administration. The thesis will attempt to prove that the differences that emerged over issues of national policy were due to deep theoretical disagreements as to the nature of the international system, the utility of power in the muclear age and the means by which to preserve detente.

An examination of the substantive policy differences will be preceded by an examination of the conceptual disagreements between the Secretaries on topics that are fundamental to any study of international politics. Studies on decision making in international politics will be used to show that each man had a different perception of the role that the United States should have in the international 
system and the usefulness of America's strategic arsenal for the preservation of peace.

After having defined the theoretical differences between Kissinger and Schlesinger on issues in international politics, an analysis of the substantive policy disagreements between the two Secretaries will show that they can be directly related to each man's conception of the intermational system. Policy differences between the two will be shown to have evolved out of disagreements over policy goals, and not policy implementation.

Any study of indivicual decision making in defense and foreign affairs stresses the importance of individual policy makers and of issues. Foreign nations perceive changes in foreign and defense policy goals when new leadership emerges with which they are uncomfortable. It will be shown, through an analysis of the foreign reaction to the Kissinger-Schlesinger controversy, that foreign nations expressed concern for the outcome of this policy split. In particular, it will be shown that the matter was of great interest to the Soviet Union. In conclusion the thesis will reiterate the point that national security decision making in the Ford Administration was unable to reach a compromise on issues of policy because of fundamental differences between the Secretaries of State and Defense on detente, the definition of the national security in the nuclear age and the negotiating strategy that America should follow with the Soviets on arms limitations. These differences on policy were made inevitable due to differing models that each Secretary had on the nature of the international system. The study of their individual perceptions will help to give one an understanding as to why the policy disagreements made compromise impossible. 
THEORETICAL DIFFERENCES IN KISSINGER AND SCHIESINGER'S

MODELS OF THE INTERNATIONAL SYSTEM

BY

Wayne Alan Schroeder

A thesis submitted in partial fulfillment of

the requirements for the degree of

MASTER OF ARTS

IN

Political Science

Portland State University 
TO THE OFFICE OF GRADUATE STUDIES AND RESEARCH:

The members of the Committee approve the thesis of Wayne Alan Schroeder, presented November 22, 1976.

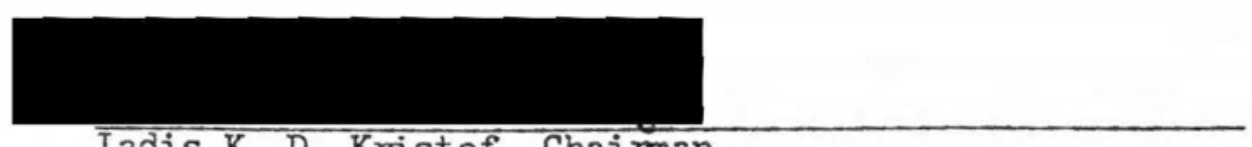

Ladis K. D. Kristof, Chairman

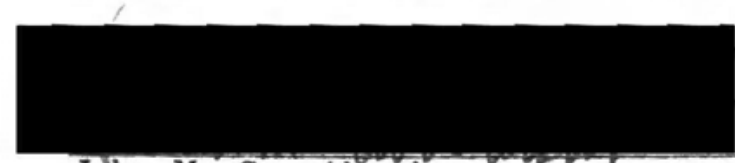

Jopn M. Swarthout

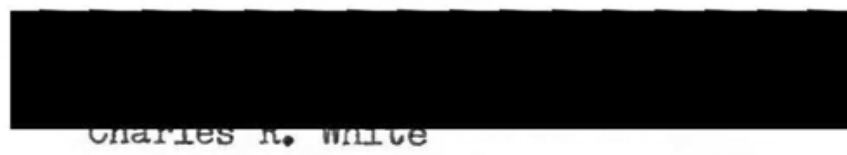

APPROVED:

Norman N. Greene, Hedd, Department of Political Science

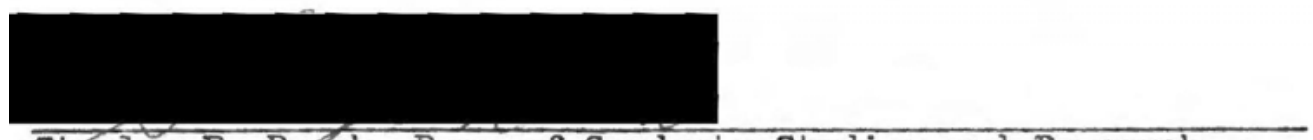

Stanley E. Rarch, Dean of Graduate Studies and Research 
TABIE OF CONTENTS

PAGE

IIST OF TABIES ..................... iv

PART ONE - OFIGINS OF THE KISSTNGER-SCHLESINGER CONTROVERSY

CHAPTER:

I AN ANALYSIS OF INDIVIDUAL AND GROUP DECISION

MAKING THEORTES FOR INTERNATIONAL POLTTICS ...

1

II KISSINGER AND SCHIESINGER:

RATIONAL AND NON-RATIONAL MODEIS OF THE

INTERNATIONAL SYSTEM ............

6

III KISSINGER AND SCHLESINGER:

DETENTE AND THE SOVIET SYSTEM $\ldots \ldots \ldots \ldots$

19

PART TWO - POIICIES AND SUBSTANTIVE DIFFERENCES

IV KISSINGER AND SCHIESINGER: POLITICAL MULTIPOLARITY V STRATEGIC BIPOLARITY • • 35

$\checkmark$ KISST NGER AND SCHLESINGER:

ISRAEL AND THE OCTOBER WAR OF $1973 \ldots \ldots$

VI KISSINGER AND SCHIEST NGER:

SAIT, DETENTE AIND NEGOTIATING STRATEGY •.... 60

VII KISSINGER AND SCHLESINGER:

THE DIA REPORT AND THE DEFENSE BUDGET $\ldots \ldots 76$

VIII KISSINGER AND SCHIFSINGER:

FOREIGN AND AMERICAN RFACTION

IX KISSINGER AIND SCHLESINGER:

CONCIUSIONS AIND COMMENTS . . . . . . . 102

BIBLTOGRAPHY ........................... 108 


\section{IIST OF TABLES}

TABIE

PAGE

I Defense Expenditures - Fiscal Year 1973 • . • • . 22

II Military Manpowers . . . . . . . . . . 23 
PART ONE

ORIGINS OF THE KISSINGER-SCHLESINGER CONTROVERSY

KISS INGER

V

SCHLESINGER 


\section{Chapter I}

AN ANALYSIS OF INDIVIDUAL AND GROUP DECISION MAKING THEORIES

The policy confrontation that emerged in the Ford Administration between Secretary of State Henry A. Kissinger and Secretary of Defense James R. Schlesinger is the focus of this thesis. If an accurate account of the reasons for the policy split is to be presented, the study of the theories of foreign and defense policy decision making will undoubtedly help in the development of a coherent description of the theoretical differences between the two men on the nature of the international system and the means by which policy decision makers should define policy goals.

The nature of foreign policy decision making is such that the policy maker must continually strive for internal consistency and cohesiveness. According to Karl Deutsch, policy is -

n.... an explicit set of preferences and plans drawn up to make the outcomes of series of future decisions more nearly predictable and consistent".l

Policy must have a consistency that will not hinder the ability of the foreign policy bureaucracy to make the policy effective.

The political nature of foreign and defense policy decision making is the most important part of the policy making process. Individuals with differing values, policy convictions and conceptions of reality converge upon Washington to make the process inherently a political one. Combined with the fact that each individual is most probably a specialist in a particular field and represents a Department

1) Karl Deutsch, The Analysis of International Relations, (Prentice Hail: Englewood Cliffs, New Jersey, 1968) p. 77 
with interests often at odds with another Department, the process of decision making becomes one of resolving differing points of view and putting them into the proper persepctive. ${ }^{2}$ This was certainly the case with Dr. Kissinger and Dr. Schlesinger.

The subordination of secondary sets of policy objectives to primary policy objectives is often the cause of internal conflict. Internal conflict must be lessened through an attempt to reach an accomodation on primary policy objectives through a process of "consensus building" ${ }^{3}$ Consensus building demands compromise. If such compromise is not reached, the very structure of the decision making system is threatened. A refusal to compromise can set off internal divisions that eventafuly must be resolved.

The inability to reconcile competing interests most probably means that differences were so great that the process of consensus building was made impossible. In the case of Secretary of State Kissinger and Secretary of Defense James $R_{0}$ Schlesinger the importance of such factors as conceptions of the nature of the international system, the problem of applying power at the right instance and in the correct amount and the very development of a national security strategy in an age of detente can clarify why compramise and consensus building was impossible.

An individual's belief system is important in the process of

2) Roger Hilsman, The Politics of Policy Making in Defense and Foreign Affairs, (Harper and Row: New York, 1971) p. 15

3) ibid., p. 177 
developing a conception of the international system. Ole Holsti's study of the belief system of John Foster Dulles concluded from a content analysis of Dulles' public statements that Dulles had a rigid perception of Soviet Communism. 4 He labeled this perception of Dulles as "the inherent bad faith of the Communist model". Dulles' point of view made any attempt at easing tensions between the U.S. and the Soviet Union quite unlikely.

The perception of the individual decision maker is one that permeates much of the literature by political scientists in the study of defense and foreign policy decision making. The actors in the decision making process often define the situation in entirely different terminology, 5 This is often due to the fact that the psychology of the decision maker is influenced by his educational and professional background. This can inevitably lead to different appraisals of what policy goals should be.

Policy goals are complicated by the fact that many inputs confuse a decision maker's perception of what actually is at issue. 6 A study of the background and writings of Kissinger and Schlesinger on such topics as power, arms control and the need to maintain a military balance will be helpful in giving us an appreciation of the

4) Ole Holsti, "The Belief System and National Images", The Journal of Conflict Resolution, VI, (1962) pp. 24山 -252

5) Richard Snyder, H. W. Bruck and Burton Spain, "The Decision Making Approach to the Study of International Politics", Intermational Politics and Foreign Policy, James Rosenau (ed.) (The Free Press: New York, 1969) p. 202

6) Robert H. Jervis, "Hypothesis on Misperception", ibid., pp. $246-250$ 
different perceptions of the two Secretaries on matters of national security policy.

Decision making by individuals in international politics can be studied also from another perspective that can help us to prove that the policy differences between Kissinger and Schlesinger were motivated by two entirely different modes of thinking. Sidney Verba's study of the development of rational and non-rational approaches to the study of decision making is very helpful in this regard. Verba develops a rational model that stresses the decision maker's cognizance of his policy goals and his desire to pursue policies that accomplish that purpose. Power is assumed to be limited by political factors. The non-rational model emphasizes such non-logical forces as fear and the personality of the decision maker. The non-rational model is less idealistic. Non-logical forces of which the decision maker is unaware help to influence his reaction to events. The decision maker's emotional involvement with the issue at hand, according to Verba, can increase "the effect of non-logical and predispositional influences".?

The rational and non-rational approaches to the models of the international system will be applied to this study of the decision making and policy differences of Henry Kissinger and James Schlesinger. A comparison of the two styles will show that deep theoretical differences were evident and that these help to explain the substantive policy differences between them.

7) Sidney Verba, "Assumptions of Rationality and Non-Rationality in Models of the International System", ibid., P. 221 
After having reviewed the individual belief systems and perceptions of Kissinger and Schlesinger, the study of the substantive policy differences between them will becane much easier to understand, and the reasons for the need by President Ford to resolve these differences will be apparent even to the harshest critics of the two Secretaries. 
Chapter II

KISSINGER AND SCHLESINGER: NATIONAL AND NON-RATIONAL MODEIS
OF THE INTERNATIONAL SYSTEM

This chapter will explore the uses of rational and non-rational models in explaining the theoretical differences between Kissinger and Schlesinger. In doing so it will show that their models of decision making originate from entirely different premises.

The non-rational model of the international system fits the decision making model of Secretary Schlesinger. It assumes that the decision maker has little control over certain aspects of the system. One good example for Secretary Schlesinger would be his approach to arms control decision making. Country A cannot cormel Country B to limit the size of its strategic forces, but it can deter the other side from initiating an attack through the use of a balance of terror strategy that makes the probability of attack less likelj•

Former Secretary Schlesinger's model places faith in "deterrence". Deterrence denotes an ability to prevent an adversary from the use of force through an equivalent or superior force. Conparability of force structures is inevitable under the deterrence approach. Schlesinger states that,

"... our defense capabilities and planning should be made in the light of the capabilities of our opponents... our planning objectives should be such that no opponent has a unilateral advantage over us". 1

1) "Flscal Year 1976 and July-September Transition Period Authorization for Military Procurement, Research and Development and Active Duty, Selected Reserve and Civilian Personnel Strengths", Hearings Before the Camittee on Amed Services of the United States Senate, February 5, 1975, 94th Congress, First Session, (U.S. Govermment Printing Office: Washington, D.C., 1975) p. if 
Schlesinger maintains that defense planning involves admitting that decision making must often be made in terms of what we must do to deter a nation from acting in an aggressive mamer, rather than what we must do to persuade them to follow a course that is rationally beneficial to them. Because of his non-rational approach to decision making, Schlesinger tends to build dichotomies about the international system that serve to reinforce his faith in deterrence, as when he states that,

"... we must recognize that we are dealing in a world that is militarily dominated by two states, ours and the Soviet Union".2

The military bipolarity of the United States and the Soviet Union Loads Schlesinger to the conclusion that the United States must retain a sieadfastness in our commitments around the world and be the major counterbalance to the Soviet Union? Detente is made possible through the maintenance of a strong military capability. 4

The concentration on Soviet and American strategic capabilities gives Schlesinger a conception of the international system in which the military-strategic balance dominates the political multipolarity

2) nFlscal year 1975 Authorization for Military Procurement, Research and Development and Active Duty, Selected Reserve and Civilian Personnel Strengths", Hearings Before the Canmittee on Armed Services of the United States Senate, February 5, 1974, 93rd Congress, Second Session (U.S. Government Printing office: Washington, D.C., 1975) p. 7

3 a

3) FY 1976 Defense Hearings, op. cit., p. 8

4) "The Nomination of James $R_{0}$ Schlesinger to be Secretary of Defensen , Hearings Before the Conmittee on Armed Services of the United States Senate, June 18, 1973, 93त्d Congress, First Session, (U.S. Government Printing Offlce: Washington, D.C., 1973) p. 43 
of the system. Power is still the dominant factor in the maintenance of international political stability according to the Schlesinger model. The strategic bipolarity of the system that Schlesinger describes makes it inescapable that the United States is the "leader of the free world" and must counter Soviet military presence wherever it presents a threat. 5

Goals of attaining detente through mutually beneficial interactions are subordinated to the strategic balance. The militarystrategic balance outweighs such factors as economic interdependence, internal domestic structures and the influence of public opinion on the nature of a nation's national security policy. The justification for large military expenditures and increases in technological capacity are generated from Schlesinger's comparative approach to the strategic military balance.

Because of the inequality of power that exists in the international system, Schlesinger sees the spread of nuclear weapons as undesirable because it would upset the stability of the strategies of the superpowers. 6 Because of the dangers of proliferation, nuclear weapons should be distributed unequally so as to discourage the chances for catastrophe.7 This forces Schlesinger into the position of defending the improvements in the strategic capability of the United States, since he objects to a Soviet daminance of the system. This reinforces his

5) FI 1976 Defense Hearings, op.cit., p. 29

6) James $R_{0}$ Schlesinger, "Nuclear Spread: The Setting of the Problemn", Selected Papers on National Security: The RAND Paper Series \#5284, September 1974, p. 13

7) ibid., p. 74 
bipolar conception of the nature of the international system.

Schlesinger's adherence to the non-rational appraach to decision making is evident in his analysis of the arms control policies of nations. It is based on the conviction that the monoply of nuclear weapons of the superpowers is a stabilizing influence and serves as a deterrent to the spread of nuclear weapons. 8 Schlesinger's belief that the rationalist approach to ams control is limited is evident in his evaluation that

"..... the nse of rational models presupposing quick perception, development and absorption of new technologies and a high degree of interaction based on astute moves and countermoves leads to a misumderstanding of the arms control problem".9

Because perceptions are limited and knowledge so often incomplete, Schlesinger denies that rationality and flexibility are inherent in the development of arms control poliey. Political decisions are "beyond the reproach" of the rational model because political decision making often neglects the technical aspects of the situation and makes a decision in terms of what is politically expedient. 10 Moreover, policy makers tend to smather differences of opinion. 11 The time element makes it difficult and sometimes impossible for national security decision makers to study problems in detail, and often forces

8) James R. Schlesinger, "Arms Interaction and Arms Control", Selected Papers on the National Security: The RAND Paper Series \# 5284, September 1974, pp. 31-32

9) ibid., p. 24

10) James $R_{0}$ Schlesinger, "On Relating Non-Technical mlements to Systems Studies", Selected Papers on the National Security: The RAND Paper Series \# 5284, September 1974, p. 76

II) ibid., p. 84 
them to rely on past experiences and the advice of their subordinates. 12 Rational decision making is impeded becanse of the limitations of human reason and kmowledge.

Schlesinger argued in favor of the nse of systems analysis in order to enable the decision maker to consider the long range consequences of potential decisians, and thereby limit the subjective preferences of the decision maker.13 Politics has to be kept to a minimum if a decision is to be effective.

Such a philosophy tends to make Schlesinger appear to be concerned with the perceptions that the other side, in most cases the Soviet Union, has of American power rather than the utility of American power itself. $\nu_{4}$ The bipolarity of the international system, the need for the decision maker to Iimit his subjective preferences and the necessity of counterbalancing the Soviet Union places the United States in the position of having to respond to each Soviet increase in strategic and military strength with a corresponding U. S. increase.

Schlesinger's perception of the Soviet-American strateglc balance and his oncern with the perception of national power illustrates that non-rational factors daminate the Schlesinger model of the international system. The strategic bipolarity of the system dominates the political multipolarity of the system and makes the relationship between the United States and the Soviet Union one that will determine the stability of the

12) ibid., p. 67

13) James $R_{0}$ Schlesinger, "The Uses and Abuses of Analysis", reprinted in the schlesinger nomination hearings, op. cit., p. 7

14) Peter J. Ognibene, "Hard Choices in the Defense Budget", Commonreal, June 6, 1975, p. 169 
entire international political system.

Secretary of State Henry A. Kissinger's model of the international system differs quite sharply from that of Dr. Schlesinger. It is rational, emphasizes the importance of politics and can be described as one that embraces "Realpolitik".

Kissinger's most important contribution to the study of international politics is his description of "revolutionary" and "legitimate" politicel systems. These two concepts, combined with Kissinger's emphasis on negotiation and diplomacy, the role of the gifted individual leader in Kissinger's writings and his belief that power has a new definition in the nuclear age confims the rational models for Dr. Kissinger. Kissinger concerns himself with the role that domestic structures and the bureaucracy have in the making of foreign policy decisions and concludes that they often impede the development of a truly creative foreign policy.

The concept of revolutionary and legitimate international systems is important in understanding the Kissinger model because it serves to determine the nature of relations between states. 15 Revolutionary systems, says Kissinger, are systems in which one or more nations refuse to accept the system itself, and desire to replace it with a new international system that corresponds to its own values. Legitimate systems are ones in which each system member is satisfled with the system, favors a retention of the status quo, and works within the system to accomplish change. This is important because Kissinger

15) Henry A. Kissinger, Nuclear Weapons and Foreign Policy, (Harper and Bros.: New York, 1957) p. 317 
believes that the Soviet Union and Communist China have increasingly shown themselves to be interested in working within a legitimate international framework and do not desire a revision of the status quo. Since the object of any international system is to preserve the peace, peace can only occur in a system where there is an acceptance of the legitimacy of the system. States that feel threatened will attempt to gain "absolute superiority" by tring to overthrow the status quo.16 Because the tendency for revolutionary powers to seek absolute security is destractive, a legitimizing principle is needed on which all nations of the system can agree. The legitimizing principle is peace.17

Peace is arrived at through the use of international agreements and negotiations that adjust differences through minimization of crises. 18 In this way the legitimacy of the international system is strengthened. Diplomacy can be used by men to gain constructive changes that will help preserve the peace. Of great importance in this process is the establishment of confidence and credibility by both sides. 19 Kissinger believes that peace serves as the legitimizing principle by which revolutionary powers can come to accept the international system. Once the legitimacy of the system has been established, it can be perpetuated through the use of diplanacy by statesmen who understand how the system operates. 20

16) Stephen R. Graubard, Kissinger: Fortrait of a kind,

W. W. Norton \& Co.s New York, 1973) p. 17

17) ibid., p. 276

18) Amos Perlmutter, "Crisis Management: Kissinger's Middle East Negotiations, October 1973-June 1974", International Studies Quarterly, September 1975, p. 346

19) ibid, , p. 331

20) Thomas J. Noer, "Kissinger's Philosophy of History", Hodern Age, Spring 1975, p. I82 
To Kissinger, the clash of competing interests is the cause of conflict. 21 For conflicts to cease, interests must be made as uniform as possible. The most opportune time for the integration of interests is when a stalemate has been reached and neither side can emerge with a distinct advantage over the other. 22 When such a stalemate has been reached, it is necessary for statesmen to build coalitions and seek partnerships so that new goals for the system can be made. ${ }^{23}$ Kissinger is cognizant of his policy goals and tries to pursue policies that will change the goal structure if there is a elash of interests. This is the so-called "mean-ends" approach for the rational model.

Kissinger's rational model of the international system is further exemplified by his concept of the individual leader. The political leader can take actions that will help to form a "structural rearrangement" of the international system. 24 The true test of diplomacy is whether it adds to the stability of the system. Kissinger's preoccupation with individual leadership is well worth noting. The elements of choice is always present, and the foreign policy choices that will be made depend on the political leadership of the nation. 25 . This reinforces his belief in the rational model for decision making in the international

21) ibid., p. 186

22) John D. Montgomery, "The Education of Henry Kissinger", Journal of Intermational Affairs, Spring 1975, p. 61

23) Ibid., p. 53

24) The New York Times, October 13, 1974, p. 34

25) Graubard, op.cit., p. 317 
system. The best example of Kissinger's falth in individual leadership is his study of the peace established at the Congress of Vienna by Metternich and Castlereagh. The personalization of diplomacy is the end result of Kissinger's concept of individual leadership.

The need for personalization is a response to the need for rational procedures through which crises can be managed. Nations can escape the fate of war and tragedy if they entrust their foreign and security policies to gifted individuals who can exercise the use of power wisely. Kissinger's elitist approach was very evident in his tenure as NSC advisor to President Nixon. Nixon and Kissinger both believed that by centralizing decision making in the NSC on foreign policy matters, they could prevent the State Department from impeding the development of the Administration's foreign policy. 26

Personalistic approaches to foreign policy decision making were favored by Kissinger because he believed that bureaucracies tend to be uncreative. 27 Bureaucracies are the greatest hindrance to individual leadership and creative action because

"... the bureaucracy absorbs the energles of top executives in reconciling what is expected with what happens; the analysis of where one is overwhelms the consideration of where one should be going... Decision making can grow 80 complex that the process of producing a concensus may overshadow the purpose of the effort". 28

26) Wilfred In Kohl, "The Nixon-Kissinger Foreign Policy System and U. S.-European Relations: Patterns of Policy Making", World Politics, October 1975, p. 7

27) Graubard, op.cit., p. 49

28) Henry A. Kissinger, "Domestic Structures and Foreign Policy", Daedalus, Spring 1966, p. 509 
While Secretary Schlesinger saw power as samething that serves to deter actors in the international system from aggression, Henry Kissinger has come to believe that power has become useless in the nuclear age. The overwhelming monopoly of power possessed by the United States and the Soviet Union often limits the ability of the superpowers to respond to crises because of the fear that the other side might intervene. ${ }^{29}$ Power is neutral, and the real power lies with the men who control the instruments of destruction. 30 The possession of nuclear weapons by the Soviet Union is not as important to the security of the United States as the composition of the Soviet Leadership and their responsiveness to our own initiatives for the negotiation of differences. This is an example of how the rational approach to decision making can be extended to Dr. Kissinger.

Kissinger sees the international system as one in which a strategic bipolarity and a political multipolarity coexist. ${ }^{31}$ He differs fram Schlesinger in that he believes that with the advent of nuclear weapons, the utility of our strategic and military arsenals is diminished. He states that

"... The most striking feature of the contemporary system... is the radical transformation in the nature of power. Throughout history power is more complex. Military power does not equal political influence... With the overwhelming arsenals of the nuclear age, however, the pursuit of marginal advantage is both pointless and potentially sucidal".32

29) Henry A. Kissinger, The Troubled Partnership, (McGraw Hill \& Co.: New York, 1965) p. 18

30) Marvin Kalb and Bernard Kalb, Kissinger, (Isttle, Brown \& Co.: Boston, 1974, p. 47

31) Henry A. Kissinger, American Foreign Policy, ( W. W. Norton \& Co.: New York, 1974) p. 56

32) Henry A. Kissinger, "Making Foreign Policy", Center Magazine, January 1974, p. 38 
Kissinger's definition of power and what it constitutes is much broader than that of Dr. Schlesinger. K1ssinger believes that nonstrategic factors must be included in the determination of national security requirements. This deflnition of national security and power makes Kissinger quite skeptical about attempts by the superpowers to gain a technological advantage over the other. 33 Improvements in the development of a national security strategy are often forfeited because of the overwhelming desire to build new technologies. Consequently the creation of defense strategies against wars of liberation, limited warfare, subversion and economic weakness are subordinated to improvements in nuclear capabilities. 34 The maximm development of power in the nuclear age must be a great concern for national security decision makers because".." with modern technology such a course must paralyze the willz".35

Strategic doctrine transcends the maximum development of power according to Kissinger. This contrasts sharply with Secretary Schlesinger's falth in deterrence and his comparative approach to determining national security needs. Kissinger's disbeltef in the adequacy of nuclear deterrence to meet national security needs 18 based on his assumption that the utility of nuclear weapons as an instrument of warfare is virtually zero. Strateglc doctrine should be flexible enough so that a pattern of response to the non-nuclear challenges can be made. 36

33) Kissinger, Nuclear Weapons and Foreign Policy, op.cit., p. 16

34) ibid., p. 32

35) ibid., p. 18

36) ibid., p. 18 
Kissinger believes that security and peace are interconnected, and that the intemational system should be less geared to crisis and more geared to cooperation. 37 Attempts to gain strategic advantage over the Soviet Union can only serve to jeopardize the stability of the newly created legitimate international system. For peace to become a reality both sides most benefit from the situation. 38 This involves, of necessity, a change in the goal structure. The political ramificam tions of intraducing conceptions of national security that are based on military and strategic factors alone can forestall the acceptance of the international system by national leaders with previously revolntionary inclinations.

Henry Kissinger's model of the international system is clearly one that is rational. Kissinger's developnent of legitimate and revolutionary systems, his belief that porer is limited in the nuclear age and his faith in the ability of men to take actions that can enhance the stability of the international system are evidences of this. To Kissinger, a definition of the national security must be broad enough so that it does not view the strategicmilitary balance as the most important determiant of policy. Otherwise the pursuit of technological advantages will be the end result, and the possibility that the legitimacy of the system will be questioned could ruin the chances for peace in the future.

37) "Namination of Henry A. Kissinger to be Secretary of State", Hearings Before the Committee on Foreign Relations of the United States Senate, 93rd Congress, First Session, Part one, (U.S. Goverrment Printing Office: Washington, D.C., 1973) p. 100

38) "Detente 1974", Hearings Before the Canm ttee on Forelgn Relations of the United States Senate, 93rd Congress, Second Session, September 19, 1974 (U.S. Government Printing Office: Washington, D.C., 1974) p. 238 
Dr. Schlesinger's model of the international system differs from that of Dr. Kissinger in that Schlesinger sees non-rational, technical and apolitical elements as important in the development of a nation's foreign and defense policies. Schlesinger's concern with the strategic balance dominates his thinking. Strategic bipolarity has been the principal reason for the success that the international systen has had in preventing the outbreak of another world war. Strategic bipolarity must be viewed compartively, and advances by the Soviet Union in strategic capabilitiesmust be taken into consideration. The United States might have to respond to Soviet technological improvements, according to the Schlesinger model, with improvements in its own technology.

Two differing models of the international system have been developed for both Kissinger and Schlesinger that depict a deep disagreement between the two Secretaries on the nature of the international system, and such concepts as power, the national security, deterrence and peace. Kissinger's concern with creating a legitimate framework in his witings causes him to question the traditional American approaches to deterrence and the national security that have accompanied American decision making since the end of the Second World War. Detente is seen by Kissinger as the outgrowth of the acceptance of the legitimacy of the international system by formerly revolutionary powers. Dr. Schlesinger sees detente made possible through a strong American military and strategic capability. Two opposing philosophies such as these give indications that substantive policy differences between the two men on issues of $U_{0} \mathrm{~S}$. nationsl security were more than likely as long as they remained in positions of responsibility in the Ford Administration. 


\section{Chapter III}

\section{KISSINGER AND SCHIESINGER: DETENTE AND THE SOVIET SYSTEM}

Detente with the Soviet Union was a major point of disagreement between Kissinger and Schlesinger, so therefore an analysis of their attitudes towards Soviet Communism and the Soviet system would help to give one an understanding of why they disagreed on detente. Individual decision makers must develop belief systems and establish attitudes about the world in which they live so that they can reduce the amounts of information they receive from the bureaucracy about foreign and defense affairs into a manageable form. Because of the need to do this, individual decision makers often reject information that does not flt into their image, or model of the international system. ${ }^{1}$ The purpose of this chapter is to examine the belief systems of Kissinger and Schlesinger, trace its development and conclude as to whether or not it could cause them to reject certain information that would trheaten their theoretical conception of the international system.

Secretary Schlesinger's bellef system was strongly related to his educational and professional background. As an economist, his analysis of the role of economics in the international system and in the national decision making process is helpful in understanding his attitudes toward the Soviet system.

Schlesinger's comparative approach to systems studies and economic analysis leads him to the conclusion that political forces dominate the

1) Karl Deutsch, The Analysis of International Relations, (Prentice Hail: Englewood Cliffs, New Jersey, 1968) p. 51 
decision making process for economics in the Soviet Union. In analyzing the Soviet economic system, and its capabilities for supporting a military incustrial complex, Schlesinger concludes that the percentage of the Soviet economy is already highly militarized. ${ }^{2}$ This has put a great strain on the Soviet economy, becanse of the increasing demands of the populace for consumer goods.

Schlesinger's analysis of the Soviet econamy concludes that Soviet military expansion has come at the cost of domestic economic goals. The fact that the Soviets have achieved large rates of industrial growth is not as important as the fact that the proportion of the Soviet econany that is need for initial resource allocations is quite low. What remains after the initial resource allocations have been made could be used for Soviet defense purposes. ${ }^{3}$ Bat the soviets do not develop economic policies on the same premises as Western nations, because political forces, not market forces, dominate the economic decision making that must accompany any determination of national security needs. 4

The political decision makers of the Soviet Union need not concern themselves with the impact of an increase in the military sector of their economy because the economy is controlled from the top down. The laws

2) James $R_{0}$ Schlesinger, The Political Econamy of National Security, (Praeger: New York, 1960) p. 57

3) James R. Schlesinger, "On Relating Non-Technical Elements to Systems Studies", Selected Papers on National Security: The RAND Paper Series \# 5284, September 1974, p. 89

4) Schlesinger, The Political Econony of National Security, op.cit., p. 169 
of mapply and demand do not apply to the Soviets, so the arguments of Western economists that the Soviets must eventually face the fact that the militarization of the economy is detrimental do not apply. The intermal weakness of the Soviet system does not convince Schlesinger that the Soviets will forego further militarization. If anything, Schlesinger is skeptical as to how an econcmy can devote such large shares of its Gross National Product to military purposes without its eventual utilization. To be assured of Sovlet good intentions, Schlesinger would first have to see a transforamtion in econamic decision making for national security purposes in the Soviet Union. He believes that the Soviet leadership does not need to conform to Western standards of increasing its attention to the demands of consumers. Besides, totalitarian nations do not need to concern themselves with the problem of resistance to militarization, and have traditionally had a larger military component in their economies than the democracies. Schlesinger's fears were in part due to the fact that the United States has fallen behind the Soviet Union in both defense expenditures and military manpower. 5 The following tables, taken fram Schlesinger's annual Defense Report for Fiscal Year 1976, show why he was concerned with these developments.

5) Fiscal Year 1976, Annual Defense Report, Secretary of Defense James Ro Schlesinger 
TABLE I

DEFENSE EXPENDITURES - FISGAL YKAR 1973

(excludes military assistance and civil defense)

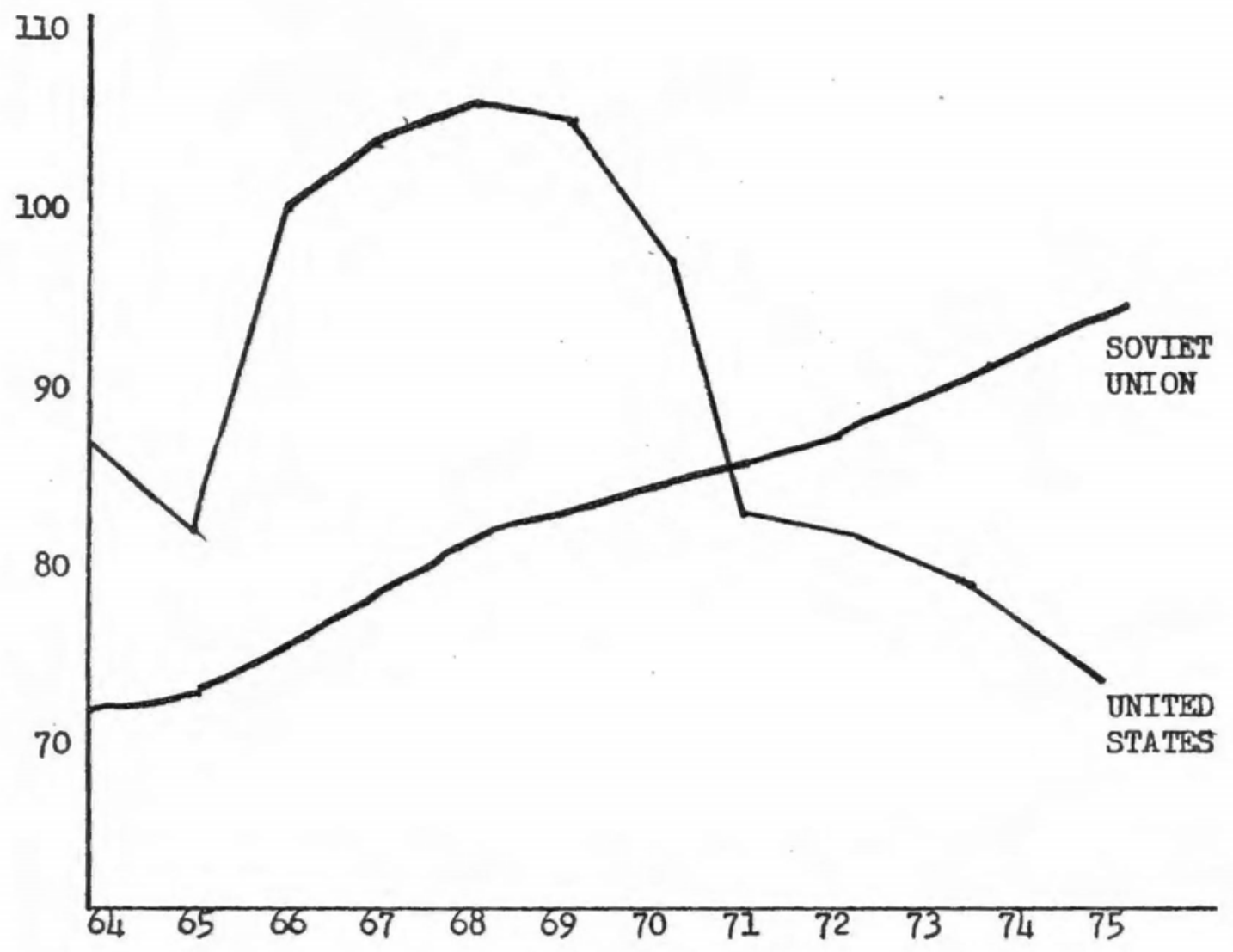

Fnd of Fiscal Year 


\section{TABLE II}

\section{MIITTARY MANPOWERS}

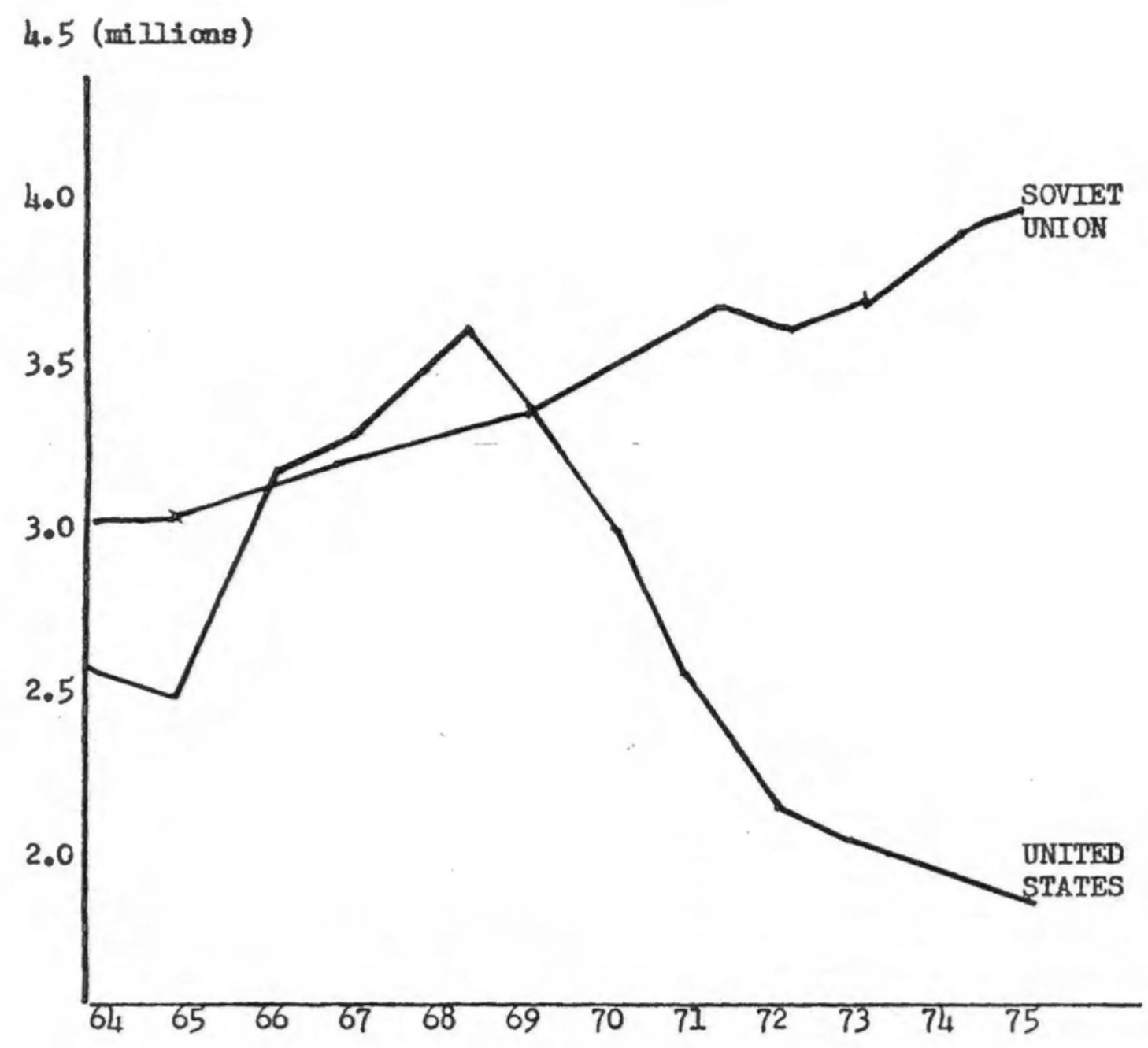

End of Fiscal Year 
Schlesinger's tendency to use comparative statistics in order to prove his point closely resembles the model that was developed for him that stressed the comparative approach to decision making. Schlesinger has reported that while the Unfted States spends less than six percent of its Gross National Product on defense related activities, the Soviet Union spends fifteen percent of its GNP on national defense. 6 In real terms the Soviets are increasing their military expenditures at the rate of three percent per year, while the United States has been shrinking its expenditures at approximately the same rate. ${ }^{7}$ The American situation is further complicated by the fact that over half of our military expenditures go into paying personnel costs, as was the case in Fiscal Year 1975, when the defense budget totaled $\$ 92$ billion and $\$ 50$ billion went into military personnel compensation. 8 The Soviets do not have the problem of giving attractive salaries in order to encourage enlistments, and can concentrate on weapons research and development.

Along with the changing military balance, Schlesinger was skeptical of Soviet intentions for ideological reasons. In spite of detente, the

6) James R. Schlesinger, "A Testing Time for America", Fortune, February 1976, p. I48

7) Ibid., p. 749

8) "Fiscal Year 1975 Authorization for Military Procurement, Research and development and Active Duty, Selected Reserve and Civilian Personnel Strengths", Hearings Before the Conmittee on Armed Services of the United States Senate, February 5, 1975, 93rd Congress, Second Session (U.S. Government Printing Office: Washington, D.C., 1975) p. 260 
Soviets' ideological stance and doctrine of the inevitable domfall of capitalism has not changed. In analyzing the nature of the Soviet threat before the Senate Armed Services Committee in 1975 Schlesinger sald that

"... we can expect from Moscow a pursuit and increase of the ideologieal struggle, and a belief on the part of Soviet leaders that detente has arrived because of a shift of historical forces in its favor..." 9

Schlesinger's skepticism about Soviet motivations for pursuing detente can be understood when his econamic and ideological criticism of the Soviet system are tkaen into account. These reservations, cambined with his emphasis on the strategic bipolarity of the international system, make Schlesinger believe that the role of the United States should be to counter Soviet influence throughout the world. Schlesinger advocates a uniformity in our defense commitments that does not account for differences in the politics of a sub-system. Such uniformity leads to a scenario reminiscent of the U.S. Involvement in Vietnam, as when he states that

"... we have Vital interests in Westem Burope, the Middle East, the Persian Gulf and Asia. Despite detente need a greater degree of steadfastness in our commitments around the world". 10

9) MFiscal Tear 1976 and July-September Transition Period Authorization for lilitary Procurement, Research and Development and Active Duty, Selected Reserve and Civilian Personnel Strengths", Hearings Before the Cammittee on Armed Services of the United States Senate, February 5, 1975, 94th Congress, First Session, (U. S. Goverment Printing Office: Washington, D. C., 1975) p. 13

10) FY 1976 Defense hearings, op.cit., p. 8 
Schlesinger belleves that this is necessary because of the fact that third parties are incapable of competing with the United States and the Soviet Union in the military and strategic spheres. II The result is the necessity for the United States to take upon itself comatments for which it might be unprepared or unviliting to wadertake because of domestic political misgivings.

Secretary Schlesinger's belief system can be said to have been gained from his training as an economist and strategic analyst. As an econonist concerned with the process of distributing goods and services to people, Schlesinger sees the Soviet system as one that centralized decision raking on the hands of a political elite who need not concern themselves with the domestic demands and inputs of its populace. The fact that the Sorlet Unton has increased military spending at the cost of donestic goals hardens his suspicion of the tra motivations of the Soviets. His analysis of the Soviet system and its ideology makes him think in terms of comparisons and dichotanies. The Schlesinger belief system, although somewhat modifled, is an extension of the post World War II attitude of the American national security making policy elite. It accepts America's role as the principal power in the world that will contest any real or perceived Soviet advance in the world. The containment doctrine is still foumd applicable in spite of detente.

17) James R. Schlesinger, whe Strategic Consequences of Nuclear Proliferation", Selected Papers on the National Security: The RAND Paper Series \# 5284, September 1974 p. 12 
The Schlesinger belief system is rigid and inflextble towards the Soviets because it insists that Soviet goals have not changed. What has changed, according to Schlesinger, is the means by which the Soviets pursue their goals. There is no consideration that the Soviets desire detente because of a need to establish what Kissinger would call a legitimate international system because of a genuine desire for peace. Schlesinger could only be convinced of a genwine Soviet desire to pursue detente if Soviet society itself underwent an internal transformation that made it sinilar to the Westem democracies.

As a political scientist, Henry Kissinger reaches similar conclusions as to the inefficiencies in the Soviet system, but he approaches the question of how this should effect America's policy towards the Soviets from an entirely different perspective from that of Dr. Schlesinger. Kissinger's concern is that the transformation of the international political system does not necessitate an internal transformation of the Soviet system itself. Extermal conditions can facilitate cooperation in spite of the internal contradictions of the Soviet and American systems.

The ideology of Commanism shapes the sense of reality of Soviet leaders in the thinking of Kissinger.12 Practical concerns enter into any leader's actions, but Kissinger sees Communism as an 1deology which dictates the perception of reality of Soviet Conmmist leaders.

12) Henry Ao Kissinger, The Troubled Partnership, (McGraw Hill Co.: : New York, 1965) p. 196 
His skepticism about the Soviet Commmist system is evident when he states that

"... In the Soviet conception man is the product of a social experience, a datum to be manipulated for his own good". 13

The Soviet emphasis on the class struggle and their belief that a socialist triumph over capitalism is inevitable are convictions that are held by both Kissinger and Schlesinger. But Kissinger's belief system differs from Schlesinger in that he regards the external influences of the international political system as of groater importance to the pursult of detente by the Soviets than the fact that they think this is the result of historical forces. Formerly revolutionary powers have begun to accept the legitimacy of the international politfeal systern, namely the Soviet Union and Conmunist China. ${ }^{1 / 4}$

Kissinger's traditional view of America's role in the world and his distrust of Communism are factors in his adherence to Realpolitik. 15 A realiam and pragmatism are apparent in his belief system that cause him to prefer a reduction in American conmil tments around the world. 16

13) Henry A. Kissinger, Nuclear Weapons and Foreign Policy, (Harper and Bros.: New York, 1957) p. 328

I4) John D. Montgomery, "The Education of Henry Kissinger", Journal of International Affairs, Spring 1975, p. 51

15) Laurence Stern, "Two Henrys Descending", Foreign Policy, Spring 1975, p. 176

16) J. Io So Girling, "Kissingerism: The Fnduring Problems", International Affairs, Joly 1975, p. 328 
The policies of the United States and other countries must conform to a rapidly changing political scene. The rapidity of change makes the need for system stability all the more important.

At one time Kissinger believed that the Soviet Union's main goal was to prevent stability. ${ }^{17}$ The Soriets would use a treaty for their own purposes, without regard for the moral or legal importance of the treaty. 18 This is very important when one considers the Kissinger negotiating strategy and the cirticisms that Secretary Schlesinger made of Dr. Kissinger's negotiating strategy with the Soviet Union on strategic arms Ifwitations.

Kissinger does not see the possibility of an internal transformation of Soriet society as likely. While the elimination of private property has "repeated all the evils of the nineteenth century", its result has been to centralize decision making in the hands of a political elfte. ${ }^{19}$ To Kissinger, the fact that power has been centralized in the Soviet system makes the chances of internal change all the more remote. Because of this centralization, disagreements on policy aro not likely to be articulated with great rigor, since the rebellious are subjected to conformist pressures.

A political evolution that changes the nature of a country's system is one that cannot be imposed fram the outside. Idealists who

17) Henry A. Kissinger, The Necessity of Choice (Harper and Bros.: New York, 1960) p. 8

18) Marvin Kalb and Bernard Kalb, Kissinger, (Iittle, Brom \& Co.s Boston, 1974) p. 60

19) Kissinger, The Necessity of Choice, op.cit., p. 295 
believe that the Soviet system will change due to our own actions, either positive or negative, do not understand how important the structure of the international system is in the process of changing the perceptions of revolutionary powers. ${ }^{20}$ An acceptance of the international system by revolutionary powers can occur without any transformation in the internal domestic structure of that state. Kissinger does not believe that we should apply Western criterion of analyzing economic indicators and military capabilities in determining the motivation of the Soviet leadership for pursuing detente. The external changes in the international system will make possible gradual foreign policy changes due to the need for stability. Kissinger has always seen ideology as one of the factors that can delay the process of legitimization in international politics. ${ }^{2 I}$ Ideology is harmful because it leads to irrationality and instability. Revolutionary states need an ideology to sustain their hopes for achievement, but ideology often blinds them as to the realities of the system and forces them to regard status quo members of the system as antagonists. Ideology fosters conflict because the dispute is not over the distribution of benefits in the system but over the system itself. Kissinger seeks to create a world order that accepts compromise of differences as an indispensable part of the legitimization process.

The need to bring the Soviet Union into acknowledging that its

20) ibid., p. 195

21) Thomas J. Noer, "Henry Kissinger's Philosophy of History", Modern Age, Spring 1975, p. 187 
best interests can be served through an acceptance of the legitimacy of the international system should be the goal of American diplomacy. Conpromise is undermined if the United States follows a bargaining technique that is inflexible. The greatest obstacle to American success in negotiating with the Soriet Union is the presence of "inoralistic formalism" that precludes the possibility that the United States could adapt its policies to fit the circumstances, 22 The United States will have to lessen its demands and adopt negotiating positions that try to build stability into the relationship between the United States and the Soviet Union.23 If the United States makes absolutely no concessions from its present position, and even tries to extract concessions out of the Soviets, we will have to risk an increase in confrontations and military expenditures. 24 This is undesirable because it would revive the doctrines of liberation and massive retaliation of the 1950 's. 25

The use of analyzing the belief systems of Kissinger and Schlesinger in regards to Soviet Communism and detente shows that while both men have a distrust of the Soviet system, they differ on whether the nature of the Soviet system makes detente possible. Schlesinger studies the Soviet

22) Kissinger, The Necessity of Choice, op.cit., p. 206

23) Henry A. Kissinger, "The Moral Foundations of Foreign Policy", Atlantic Cormunity Quarterly, Fall 1975, p. 21

24) "Nonination of Henry A. Kissinger to be Secretary of State", Hearings Before the Conmittee on Foreign Relations of the United States Senate, 93rd Congress, First Session, Part One, (U.S. Government Printing Office: Washington, D.G., 1973) pp. $116-177$

25) "Detente 1974", Hearings Before the Comnittee on Foreign Relations of the United States Senate, 93rd Congress, Second Session, (U.S. Goverment Printing Offlce: Washington, D.C., 1974) p. 246 
system as an economist and concludes that the politicization of the economy means that all motivations have to be political ones. He is concerned that detente could be misrepresented as entente and that the American people would come to feel that the maintenance of a strong military was no longer necessary. Above all Schlesinger is concerned that the price of detente not be too high.

Kissinger discounts the need for internal changes on the part of the Soviet systen as a prerequisite for a Soriet acceptance of the legitimacy of the international system. Soviet leadership has come to accept the status quo. Nations with different nationalities, ideologles, religions and values can share a common desire for peace that transcends the diversity that canplicates the process.

Tro belief systems such as these are perhaps inevitable due to the professional backgrounds of the two Secretaries and their areas of expertise. Yet the problem of coordinating foreign and defense policy and developing a national security strategy in the Ford Administration was complicated by the differing theoretical models and belief systens of the two men, in spite of these generally anti-Commmist opinions that were critical of the Soviet system. Kissinger's global outlook, and his attempt to create a theory of peace by which nations can live together in harmony could cause him to overlook changes that could occur in the strategic-military balance. And likewise, Schlesinger's comparative approach to the analysis of American national security requirements could make him minimize the importance of political factors and also to reassure Soriet leadership of American peaceful intentions. As detente contimued throughout the Nixon era and into the reign of 
President Ford, a debate within American national security policy making circles was inevitable, with the question being over the means by which to preserve detente in an age of strategic parity. 


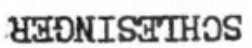

$\bar{\Delta}$

सGXNISSIT

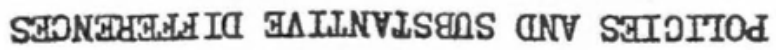

$\overline{\text { OMI JसYQ }}$ 


\section{Chapter IV}

\section{KISSINGER AND SCHIESINGER: POLITICAI MULTIPOLARITY V STRATBGIC BI POLARITY}

The analysis of the theoretical differences in Secretary of State Henry Kissinger and Secretary of Defense James Schlesinger's models of the international system have shown that differences existed in regards to the nature of the system, the utility of power and the role that the United States should play in world affairs and in its relations with the Soviet Union. What is evident is that a continuing debate over the importance of America's national security policy was to emerge. This is perhaps best demonstrated in the policies advanced by the two Secretaries. The purpose of this chapter is to review the most important policy contributions that Kissinger and Schlesinger made in the last Republican Administration and show that the impartance of strategic bipolarity in the international system was approached from two entirely different perspectives. This is particularly true in the case of Dr. Schlesinger, whose reign as Secretary of Defense was to disturb the Soviet Union.

\section{Schlesinger: Retargeting Enhances Deterrence}

As Secretary of Defense, Dr. Schlesinger developed a retargeting polfey for our muclear weapons arsenal that demonstrates his belief that deterrence helps to make detente possible, and that deterrence Is enhanced through a flexible and diversified nuclear attack force. Schlesinger's comparative approach to the military and strategic balance caused him to Fier increases in the Soviet strategic capability with alarm. In the light of the Soviets' increased capability, 
Schlesinger observed that a more flexible and selective policy was needed in U.S. nuclear strategy than the policy of "mutual assured destruction" (MAD), that had been developed by former Defense Secretary Robert McNamara in the Kennedy and Johnson Administrations. The Schlesinger policy was to give the President a greater flexibility as to the targeting of $\mathrm{U}_{.}$. missiles on targets in the Soviet Union. I Instead of targeting only upon population centers, targeting options would also include Soviet military targets. This is the somcalled "counterforce" strategy.

Based on the concept that mutal deterrence would increase if the cost of starting an attack was the risk of suffering immediate attack on population centers, the mutual assured destruction policy was seen by Schlesinger as incapable of preventing a possible nuclear conflict from degenerating into anything other than a massive slaughter of the cities. MAD had originated in an age of U.S. strategic superority, but with the advent of nuclear parity, a policy change was deemed necessary by the Nixon Administration under Schlesinger's direction.

The Soviets reacted strongly to the change in American targeting strategy. The perception received was that the United States was now preparing a first strike capability against Soviet strategic targets. ${ }^{2}$

1) Fiscal Year 1975 Authorization for Milftary Procurement, Research and Development and Active Duty, Selected Reserve and Civilian Personnel Strengths, Hearings Before the Comittee on Armed Services of the United States Senate, 93rd Congress, FIrst Session, February 5, 1974 (U.S. Goverment Printing Office: Washington, D.C., 1974) p. 7

2) G. W. Fathjens, "Flexdble Response Options", Orbis, Fall 1974, P. 679 
The Nixon Administration received much criticism for this retargeting change from the Congress. Senators Thomas McIntyre (D-New Hampshire) and Walter Nondale (D-linnesota) were especially vocal in the criticism of the retargeting change. ${ }^{3}$ Their fear was that the policy change introduced a destabilizing element into the muclear ams race. The Soviets come to distrust Schlesinger because of 1 t.

What counterforce has done, said Schlesinger, is to enhance deterrence by introducing a mechanism that can control a sequence of events from escalating into a nuclear holocaust, by moving array from the assured destruction concept. 4 Schlesinger himself raled out the possibility that the United States would ever strike first, stating that the U.S. does not possess the capability to eliminate all of the Soviets' missiles in a first strike. ${ }^{5}$ Its purpose is to strike at strategic Soviet targets if the Soviets should initiate a limited flrst strike, where not all of 1ts strategic arsenal would be used against the United States.

The purpose of the polfcy change was to ellow nuclear conflicts, in the event they did occur, to be brought to a more rapid conclusion with as little damage as possible. 6 schlesinger stated that the polfey

3) The Congressional Quarterly, August 9, 1975, p. 1746

4) Donald $R_{0}$ Westervedt, "The Essence of Armed Futility", Orbis, Fall 1974, p. 705

5) FY 1975 Defense Hearings, op॰cit., p. 461

6) ibld., p. 38 
change brought American strategic policy into line with that of the Soviets. 7

Further criticism of Schlesinger's counterforce strategy was based on the fact that it would open the door for a full scale escalam tion of anti-ballistic missile systems. With nuclear war having become more manageable, it also might become more thinkable. But Schlesinger discounted these criticisms, again stating that the principal aim of counterforce was to enhance deterrence. 8 The MAD theory was to be discredited in Schlesinger's view, because it agreed that the defense of eivilian populations was not possible, when indeed, a counterforce strategy that guaranteed the use of smaller weapons would reduce the collateral damage to population centers near military targets.9 Overkill could become obsolete as a criticism to limited nuclear war with the implementation of counterforce strategies as opposed to mutual assured destruction.

Deterrence would be enhanced under counterforce through the creation of numerous strike options for the President because it gives the President flexibility in a crisis. 10 Crisis decision making could be made more manageable, and a potential Ifmited first strike by the Soviets, or even the Chinese, could be deterred through

7) William $R_{0}$ Cleave and Roger W. Barnett, "Strategic Adaptability", Orbis, Fall 1974, p. 674

8) The Congressional Quarterly, August 9, 1975, p. 1746

9) Juan Cameron, "The Rethinking of U.S. Defense", Fortune, December 1973, p. 84

10) "The Schlesinger Gamble", The Econamist, March 2, 1974, p. 18 
the use of flexible strike options.

Secretary of State Henry Kissinger had written that the possibility of a limited nuclear war, or even the use of nuclear weapons for tactical purposes should be planned for. 1 ll Kissinger himself had come to believe that the mutual assured destruction theories were no longer operable in the era of strategic parity, and he doubted that the United States had enough missiles to bring credibility to the MAD thesis. ${ }^{12}$ The American SALT I agreement with the Soviet Union had covered numerical limitations, such as the number of intercontinental ballistic missiles, submarine launched ballistic missiles and the number of anti-ballistic missles allowed in the ABM treaty are good examples. But qualitative increases and the problem of the throwweight, or payload that the missiles carried were not. The Soviets could technically comply with the agreements reached at SAIT I without having to worry about placing larger missles in silos that were designed for smaller ones. The seriousness with which the Soviets were to have negotiated the SALI I agreement was evident by the fact that they accepted strict limitations on radar developments. 13 Nuclear parity was quantitative, but the possibility that a qualitative arms race could ensue was a real possibility. This was to be a dispated point between Kissinger and Schlesinger that helped to trigger disagreements over SALT I, U.S. arms negotiating strategy and the possibility of Soviet violations of the SALT and ABM agreements.

17) Henry Brandon, The Retreat of American Power, (Doubleday: New Yark, 1972) p. 28

12)ibid., p. 301

13)ibid., p. 315 


\section{Klssinger: A practitioner of Macropolitics}

Eventually, a conflict between Kissinger and Schlesinger's approaches to national security policy were bound to emerge. Kissinger had always thought of international political problems in terms of great issues rather than the comparative strategic balance of power. It $\mathrm{His}$ macropolitical approach is dise to the fact that Kissinger felt that a preoccupation with milltary and strategic bipolarity often causes rigidity in the political actions of nations. This rigidity should be lessened through the acceptance of "world policy and institutions". 15 In this manner security consciousness will also be diminished. American foreign policy, of necessity, must reconcile the concepts of strategic bipolarity and polttical multipolarity. The Secretary saw this as the major issue confronting American policy makers in the next era. 16 Ironically, Kissinger spoke in this instance of what was the fundamental point of dispute between himself and Secretary Schlesinger. The resolution of America's security requirements as opposed to the political necessity for obtaining an ams agreement with the Soviet Union was the primary area of dispute between the two. Should the United States accept arms agreements that will enhance the stability of detente, even though they might put the U.S. in a strategic disadvantage

24) The Economist, October 19, 1974, p. 13

15) The Econconist, July 19, 1975, p. 48

16) Alastair Buchan, "Irony of Kissinger", International Affairs, July 1974, p. 373 
to the Soviets? Should the United States attempt to maintain its nuclear capabilities, increase its sitrike options and continue to improve its technological advantage over the Soviets at the risk of losing the political relationship it has with the Soviet Union at the present moment?

From another persepctive the Kissinger-Schlesinger split can be analyzed from a policy viewpoint in terms of their perception of what America's role in the world should be at the present time. Naclear parity had been found to be the fact by Secretary Kissinger when President Nixon ordered him to make a strategic assessment of US-Soviet strategic capabilities in December of 1968. ${ }^{17}$ This, combined with the trauma of the Vietnam and the dowestic internal problems of the United States made the Nixon-Kissinger team formulate a new foreign policy for the United States in the early years of the Nixon Administration. Kissinger had come to doubt the faith of former Secretary of State Dean Rusk that American power was eapable of achieving great goals, and he feared that a continuation of such a policy would produce a great strain on American leadership and raise public expectations to levels that could not be maintained over long periods of time. 18

Kissinger and Nixon perceived a world in which America's power to gain any objective was limited by its resources, the will of Its people and the strength of its political leadership. Kissinger helped

17) Marvin and Bernard Kalb, Kissinger, (Isttle, Brown and Co.s New York, 1974) pp. 106-107

18) Ibid., p. 65 
to replace the old Cold War idealism with a "strong dose of Realpolitik and self interest. 19

Schlesinger's emphasis on strategic bipolarity leads him to the opposite conclusion. The stability of the international system has been threatened by the rentrenchment of American power, and Schlesinger belleved that an imbalance could occur, in the favor of the Soviet Union, unless the United States is prepared to take the necessary unilateral measures to reverse this imbalance. Schlesinger feared that "the spectre of Soviet hegemony" presently exdsts in Europe and that recent increases In Soviet naval strength in the Indian Ocean and the Far East had dramatically changed the structure of the intemational system from a military standpoint, 20 Schlesinger has recently written that,

"Steadily the entire world is becoming a single strategic state... (it) can no longer be divided into widely separated theaters, " 21

Schlesinger's appraisal of the weakness of the American position at this time is based on the conviction that it is the United States, through its hesitancy and indecision, that is respensible for the current tendency of nations to Iine up against the United States on political issues.22 The desire of the United States to reduce its

19) Brandon, op.cit., p. 42

20) James $R_{0}$ Schlesinger, "Atesting Time for America", Fortume, February 1976, pp. 75-76

21) James $\mathrm{R}_{0}$ Schlesinger, "The Continuing Challenge to America", The Reader's Digest, April 1976, p. 63

22) FY 1975 Defense Hearings, op॰cit., p. 5 
commitments is dangerous because of the fact that nations will look elsewhere for military assistance and alliance partnerships.

From a policy analysis of the need for nuclear flexibility in targeting and the need for reaching political agreements on nuclear arms limitations, it can be seen that the problem of resolving the issue of strategic bipolarity versus political multipolarity was one that would eventually separate the two men. Kissinger's insistence that this issue was the most crucial facing American foreign policy was accurate. The two Secretaries developed policies that differed on the conception of which of the two ideas would best be able to bring international political stability to the-international system. This caused them to favor differing policies as to what America's defense cormitments should be and whether or not deterrence was reliable in the nuclear age.

Kissinger's desire was to create a structure of peace through political arrangements. This is evident in his remaric that

"... you should be able to use crises to move the world towards the structural solutions that are necessary. In fact, very often crises themselves are a sympton of the need for structural rearrangements". 23

Kissinger was thinking in terms of making a system that is traly cooperative and cognizant of the fact that interdependence forces nations to work within worldwide institutions. There exists within the international system many areas of conflict, not just two. 24 . The

23) The New York Times, October 13, 1974, p. 35

24) Henry A. Kissinger, "Address to the Sixth Special session of the United Nations General Assemblr", International Organization, Sumer 1974, p. 574 
problem Kissinger was trying to solve, in the words of Premler Alf Bhutto of Palcistan, was one of

"... evolving the foreign policy of a country striving to build a new world order, not on the ashes of war, but in times of peace". 25

In the Xissinger view, political multipolarity is potentially more dangerous than strategic bipolarity because of the fact that political disagreements between sub-systems could lead to a polarization of the international system into the $U_{0}$. and Soviet camps. Nations could use their resources as political weapons. ${ }^{26}$ The Kissinger concern for preventing the politically multipolar system fram breaking down into two camps contrasts sharply with Schlesinger's concern for establishing mechanisms that can prevent a non-cooperative world from destroying itself.

Foreign and defense policy could be expected to eventually be at odds. Strategic bipolarity and polftical multipolarity, as concepts With which American national security decision makers must deal, were complleated at this time because the United States was following a defense policy that encouraged increasing muclear strike options and improving U.S. technological capacity, while Secretary Kissinger was in the process of negotiating a SAIr II agreenent that hopefolly would conclude with as much success as SAIT I. At the same time, the

25) "Kissinger: Positively Negative", Far East Economic Revien, November 15,1974 , p. 574

26) Henry A. Kissinger, "The Washington Fnergy Confeerence: The American Chall enge", The Atlantic Community Quarterly, Spring 1974, p. 25 
American public was to believe that detente had truly arrived, and that there was no need for the United States to undertake the active defense of nations, either through direct involvenent or military assistance, The paradox of seeing the President of the United States sign a SALT I agreement with the Soviet Union and embracing detente, and at the same time order the mining of Haiphong Harbor in North Vietnam seemed inconsistent to the Arerican people, and a neo-isolationist trend ensued. How is detente to be maintained and wat are its limitations were to be issues that split the Ford Adrinistration in its development of a national security policy. The proper definition of what is the national security in an age of detente, and how it should be defined in comparative or normative terms were issues that eventually had to be resolved. These issues were left unanswered, until the President saw that his two Secretaries were working at cross purposes. The substantive issues on which Kissinger and Schlesinger disagreed will prove that the coordination of defense and foreign policy is made difflicult unless decision makers make efforts to develop common perceptions of what is at stake and what choices will enhance the national security need of the United States. 


\section{Chapter V}

KISSINGER AND SCHIESINGER: ISRAEL AND THE OCTOBER WAR OF 1973

Any two national decision makers, when confronted with an issue that demands the immediate attention of the President, bring into the national security decision making process perceptions about the issue that can influence the recommendations they make to the President. The ideological orientation of the decision maker, his belief system and theoretical model of the international system and his own personal values often cause him to think in terms of the global implications of a dispute at the sub-system level.

Such was the case in the development of the Nixon Administration's policy towards resupplying Israel during the 1973 October War. Secretary of State Kissinger and Secretary of Defense Schlesinger were the primary decision makers for the United States besides the President, during this crisis. The study of the Kissinger-Schlesinger relationship during the 1973 October War is important because:

1) it was a crisis situation and could give one clues as to possible relationships between the two Secretaries in future crises;

2) it gives us the chance to examine the nature of the KissingerSchlesinger relationship from the standpoint of which Secretary had the most influence with the President, which will enable us to understand why Schlesinger came to protest American national security policies in the next two years; 
3) it gives us the opportunity of examining the charge that Secretary Schlesinger deliberately violated orders in regards to the resupplyIng of the Israelis, and the charge that Kissinger, in fact was the one who was really responsible for the resupply delays.

Any President must have a high degree of confidence in his cabinet members and advisors during any crisis decision. The expertise of the members of the foreign and defense bureaucracies often forces the President to rely on their knowledge in the making of national policy. According to Morton Halperin, a former aide to Henry Kissinger when he was on the National Security Council staff,

"Power gravitates to those individuals who are willing to make decisions and live with the results".l

Henry Kissinger had gained the confidence of President Nixon due to the fact that by October of 1973 he had worked with Nixon for over four years and had the President's confldence. As NSC advisor to the President, Kissinger held thirty-seven NSC meetings in 1969. In his first year as Secretary of State, however, Kissinger held only four NSC meetings. ${ }^{2}$ Schlesinger became Secretary of Defense in the spring of 1973. With Kissinger holding fewer NSC meetings with Schlesinger as Secretary of Defense, it would seen probable that Kissinger had a very dominant position in the control of information that President Nixon received on national security matters. This is very important to remember when an evaluation of responsibility for the resupply

1) Morton $\mathrm{H}$. Halperin, Bureaucratic Politics and Foreign Poliey, (The Brookings Institution: Washington, D.C., 1974) p. 220

2) The Ner York Times, Decenuber 2h, 1973, p. 4 
delays is to be made.

Secretary of Defense Schlesinger had little influence with the President at this time. With the reputation of being a hard-nosed and no-nonsense individual, Schlesinger had little desire for making friends through persuasion, was often at odds with many of his colleagues. Schlesinger's problem was to gain access to the President in a way in which Kissinger could not control the means of cormunication with the Chief Executive.

Schlesinger consequently could not be expected to have the same flexibility as did Kissinger in conceiving policies, because of the communication problem. Although having served for four years in the Nixon Administration in a variety of positions, from Atomic Energy Conmissioner to the Director of Central Intelligence, Schlesinger did not have a close working relationship with the President. ${ }^{3}$ In the 1973 October war, Schlesinger could not be expected, fram an analysis of his relationship with Kissinger and Nixon, to have much input on the substance of policy.

A further background in the study of the Kissinger-Schlesinger relationship in this instance should be prefaced by the examination of how the cammunications between the two Secretaries had been established in 1973. Upon becoming Secretary of State, Kissinger began a series of contacts with Schlesinger in which they would try to see each other for breakfast "at least once a week". 4

3) "Schlesinger on Defense", Aviation Week and Space Technology", October 21, 1974, p. 10

4) The New York Times, December 24,1973, p. 4 
They also communicated by phone quite frequently. This commmication continued for nearly two years until an open hostility between the two Secretaries became apparent to all. These sessions would appear to be ones in which the Secretary of State was to serve as a means by which the President could convey to Schlesinger any new policy decisions and in which Kissinger alone could control Schlesinger's inputs as to criticisms that national security decision makers should consider. The point is that Kissinger dominated the national security decision making process by limiting Schlesinger's opportunities for criticism through holding infrequent NSC meetings and also dominating the access to the President.

The outbreak of the 1973 October war caught both the Israelis and the Americans by total surprise. Secretary of State Kissinger stated that both the American and the Israeli intelligence networks had reported one week prior to the Arab attacks that there was no chance of war breaking out in the near future. 5 Once war did break out, Kissinger was directed by President Nixon to organize the Washington Special Action Group, WSAG, which was responsible for making foreign policy decisions for the United States during the October war. The WSAG group consisted of Kissinger and Schlesinger, Undersecretary of State Joseph Sisco, Deputy Secretary of State Kenneth Rush, CIA Director William Colby and

5) Avi Shlaim, "The failure of National Intelligence Estimates: The Case of the Yom Kippor War", World Politics, April 1976, p. 361 
the Chairman of the Joint Chiefs of Staff, Admiral Thomas Moorer. 6 The day after the outbreak of the war Secretary of Defense Schlesinger and Admiral Moorer met with top Israeli experts to begin a determination of the ability of the Israelis to withstand the Arab attacks. 7

Israel was in a strategically poor position. The Syrians had crossed the Israeli defense lines on the Golan Heights and the Egyptians had moved across the Suez Canal to its east bank. ${ }^{8}$ No one in the Administration believed that a massive airlift to Israel was necessary at this time. The U.S. held the conviction that in spite of the strategic situam tion, Israel would easily win the war, and the U.S. would not have to risk resupplying the Israelis if they needed spare parts and armunition.9 The policy of the Administration between the day of the outbreak of the war and the day on which the Soviets first began to supply the Syrians and the Egyptians was to give the Arab block the impression that the United States was trying to remain neutral. This was the so called "Iow profile" policy of the United States. 10

Against this background the accusations that Secretary of Defense

6) Marvin and Bernard Kalb, Kissinger, (Iittle, Brown and Co. 2 Boston, 1974) p. 461

7) The New York Times, October 7, 1973, p. 1

8) Kalb and Kalb, op.cit, p. 464

9) William Bo Quandt, "Kissinger and the Arab-I sraeli Disengagement Agreement", Journal of International Affairs, Spring 1975, p. 37

10) Ieslie $\mathrm{H}_{0}$. Gelb, "Kissinger and Schlesinger Deny October Páft", The New York Times, June 23, 1974, p. 10 
Schlesinger impeded the delivery of arms shipments to the Israelis should be noted. According to this account, the Secretary of Defense obstructed the shipment of phantom jets to Israel and delayed the chartering of civilian planes to Israel for resupply purposes. 11 Schlesinger reportedly refused to meet with Israeli contact to the United States during this period, Simicha Dinitz, on October 10th for the purpose of discussing the matter of transferring military aid to Israel. Schlesinger was said to have disagreed with Kissinger over the chartering of twenty civilian planes to Israel for the purpose of flying emergency supplies to them.12 Schlesinger was also said to have told Dinitz that the United States could fly supplies only as far as the Azores Islands on October 17th, after having received word from Kissinger that the United States: was was to use civilian charters for the resupply effort. After this last bit of intransigence on the part of Schlesinger, President Nixon was to have ordered a meeting on Saturday October 13th in which he personally ordered for the use of C5-A military transport planes for the resupply effort, and that they were to bypass the Azores and go directly to Israel. 13

Both Secretary of State Kissinger and Secretary of Defense Schlesinger denied this account. In doing so they both acknowledge that Schlesinger was not in the position of being able to impede the

11) Kalb and Kalb, op.cit., pp. 466-468

12) Kalb and Kalb, op॰cit, , p. 472

13) Kalb and Kalb, op॰cit•, pp. 476-477 
implementation of U.S. policy at this time because of the dominance of Kissinger. Schlesinger stood by the story that he did not receive any authorization from the White House to send military aireraft to Israel until the morming of October 13th, and that while he did try to get American civilian charters to transfer the goods and supplies to Israel, American companies refused to cooperate. ${ }^{1 / 4}$ The delays were a part of national policy. While the United States agreed to supply munitions to the Israelis, the Military Airlift Command, (MAC) was not to be used. The private sector refused to cooperate with the Pentagon, because of the fact that charter companies feared the prospect of reprisals by the Arabs.

Both Kissinger and Schlesinger were anxious to "break the Soviet stranglehold", in parts of the Kiddle East. ${ }^{15}$ American policy has already been said to have been predicated on the hope that the United States would not have to resupply the Israelis in the October war. It was not until October loth that the Soviets began to resupply the Syrians and the Egyptians. American policy during the period of October 10th to October 12th can be said to be that of attempting to get civilian charter companies, through the Pentagon, to get the supplies sent to Israel. The Americans still had the hope that they would not have to use military aireraft to send the supplies.

$\left.I_{4}\right) J_{0} I_{0}$ Schecter, "Schlesinger and the Resupply Crisis", Time, July 1, 1974, p. 33

15) Ieslie H. Gelb, "Schlesinger for Defense: Defense for Detente", The New York Times Magazine, Angust 4, 1974, p. 43 


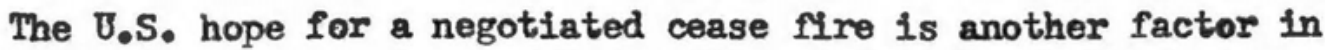
the refutation of the story that Schlesinger is to blame for the resupply delays. On October 12th the Israelis agreed to U.S. proposal for a "stand in place" cease fire. 16 The Soviets claimed that the Egyptians would also accept it, if neither the United States or the Soviet Union took the issue to the United Nations. But when Sadat of Egypt rejected the proposal, it became clear to President Nixon that the chances for a negotiated cease fire had vanished, and so the next morning he ordered the military airlift to Israel.

Was Schlesinger the one who was stalling on the arms shipments to Israel, or was it Nixon and Kissinger? Nixon and Kissinger had the better motivation for stalling on the resupply effort, and it was Kissinger, not Schlesinger who was in charge of the WSAG group coordinating J.S. policy at this time. The American leadership feared the possibility of an Arab oil embargo, and hoped to and the war with a negotiated cease fire before there was a need to resupply Israel. Kissinger himself should bear the majority of the responsibility for the decisions that were made, because of the fact that he did control the IISAG group and for the fact that President Nixon was preoccupied with the resignation of Vice-President Agnew and his own Watergate difficulties. A more believable account would have Kissinger using Schlesinger to take the criticism from the Israelis while he was maling a political reassessment of the situation in hopes of arriving

16) Quandt, op.cit., p. 37 
at an end to the conflict through negotiation. ${ }^{17}$

America's resupply effort was piecemeal and halfhearted at first because this was national policy. Secretary of State Kissinger had a very real concern that the October War could escalate into a confrontation between the United States and the Soviet Union. Kissinger himself refused a military airlift to Israel and organized a plan in which the United States would send supply planes only as far as the Azores, because he wanted Soviet-American cooperation doring this crisis. 18 A review of the criticism from Congress towards the Administration at this time shows that it was the entire Adminstration that was being subjected to Congressional attacks. Senator Henry M. Jackson (D-Wash.) accused the Administration of

".... withholding the means of self-defense from a friend at $\operatorname{war}^{n} .19$

Secretary of State Kissinger's concern curing the October War of 1973 was to preserve the stability of detente. The war between the Israelis and the Arabs threatened to destroy the international system by forcing the United States and the Soviet Union to back each side. This was the first real test of detente. American policy was developed at this time in a manner that meant to localize the conflict and prevent

17) Ieslie Ho Gelb, "Kissinger and Schlesinger Deny October Rift", The New Yark Times, Jume 23, 1974, p. 10

18) Edward Inttwak and Walter Laquer, "Xissinger and the Yom Kippur War", Commentary, September 1974, pp. 36-38

19) Time, October 22, 1973, p. 51 
the superpowers fram reaching a showdown from which escalation of the conflict would mest probably result.

Wile Kissinger and Schlesinger can be said to have been in agreement over the goal of preventing $U$. S, Involvement in the war, they disagreed over whether the Soviet Union would actually intervene. President NHxon ordered Kissinger to take charge of the U.S. response to the Soviet threat that they would unilaterally intervene in the war by placing a peace keeping force in the area. The Soviets had put four of their airborne divisions on alert and had sent flive transport ships to the Mediterranean. President Nixon had opposed using a big power peace keeping force in settling the conflict, but Premier Breshnev of the Soviet Union asked Nixon to consider a joint U.S.-USSR peace keeping force that would be sent to Egypt. Breshnev stated that if the J.S. didn't accept the plan, the Soviets might intervene unilaterally. 20 Nixon ordered the Secretary of Defense to alert all U.S. forces stationed around the world upon hearing Breshner's statement. Secretary Schlesinger was responsible for the implementation of the alert, but he disagreed with Nixon and Kissinger's appraisal that Breshnev should be taken seriously. Schlesinger was quoted as saying that

"I think the probability of Soviet forces being on route was considered by some to be Ior". 21

Whether the sending of the Sovlet transport ships to the Hediterranean and the placing of four Sovlet airborne divisions on

20) Kallb and Kalb, op.cit., p. 489

2I) Kalb and Kalb, op.cit., p. 497 
alert was an indication of possible Soviet intervention or not, Nixon and Kissinger were prepared for the possibility. Kissinger's efforts to prevent the big powers from involving thenselves militarily in the Detober War is an indication that he believed that the future of detente could well rest on the ability of the United States and the Soviet Union to pacify the situation. Schlesinger was thinking in terms of capabilities and strategies.

The two Secretaries also differed on their own personal handing of Western $\mathrm{B}$ uropean reaction to the American resupply effort. The Buropeans opposed the use of NATO facilities for the resupply effort. 22 Schlesinger critleized West Germany for taking a "separate line" from that of the United States in the crisis, and specifically referred to West Germany's call on the U.S. to stop loading American supplies and weapons for Israel on to Israeli freighters at the U.S. forces port in Bremerhaven. 23

Iater, in the month of November, Schlesinger met with West German Defense Minister Georg Leber and together they worked out an arrangement that provided that in the future United States military equipment would not be sent from West Germany on Israeli ships. 24 Schlesinger had been able to reach a compromise with the Fest German, and did 80 in a way that might help the United States in case of another confifct in the widdle East. Schlesinger's concern for NATO and the structure of the

22) Nadar Safram, "The War and the Future of the Arab-Israel1 Conflict", Foreign Affairs, January 1974, p. 224

23) The Herw York Times, October 27, 1973, p. I

24) The New York Iimes, November 10, 1973, p. 13 
Alliance were important considerations in this matter. The perception of Western cooperation was deemed important.

This contrasts sharply with Secretary Kissinger's handling of the Western European problem. Kissinger's criticism of NATO was very heated, and he is said to have been "disgusted" with the failure of NATO to back the United States in the crisis. ${ }^{25}$ The Europeans apparently had little desire to see their own economies hurt due to a possible West European-U.S. Iinkage during the resupply effort, after which the Arab nations would place an oil embargo on them as well as the Americans. European hostility to Kissinger continued for the next two months, in spite of the fact that the Americans and West Germans had reached an agreement on resupplying Israel in November. The Europeans were extremely resentful of Kissinger's criticisms as late as November 29th of that year. 26 Kissinger had less of a concem th the strength of the NATO Alliance, and concerned himself with preventing a SovietAmerican confrontation.

Secretary Kissinger's primary role during the 1973 October War was that of "crisis manager". 27 As a crisis manager, he has been shown to be concerned with three specific situations in which it was proved that Kissinger was more concerned wi th preserving the "structure of peace" and preventing a Soviet-American confrontation in the area than he was with reaching a rapid conclusion to the conflict by resupplying Israel when it

25) The New York Times, October 31, 1973, p. I

26) The New York Times, November 29, 1973, p. 43

27) Roger Morris, "Kissinger and the Brothers Kalb", The Washington Konthly, July/August 1974, p. $55^{\circ}$ 
needed weapons and arms, Kissinger, and also former President Nixon, saw the October War of 1973 as a potentially destabilizing event for the system. The future of detente, according to the Kissinger logic, was threatened by an overt show of American support to Israel. The resupply delays were meant to allow the United States to maintain a low profile during the conflict. The fear of Soviet intervention led to a worldwide alert of all American forces. The failure to consult with Nest Germany and other NATO countries on the resupply effort and the alert was motivated from a fear that they would not support such a policy, so the United States must go ahead without their consent. Kissinger's desire was to preserve the structure of peace, by using peace itself as the legitimating principle that would force nations to recognize that it was in their best interest to preserve the status quo. ${ }^{28}$

Secretary Schlesinger's concern during the 1973 October Nar was that of implementing the Nixon-Kissinger policies and maintaining a strong Western Alliance. The study of policy making at the individual level during the 1973 war for both Kissinger and Schlesinger proved that Schlesinger at this time was not in a position to challenge Administration policy effectively, because of the doninace of the Secretary of State in the formulation of American national security policy. Schlesinger's behavior during the resupply crisis contrasts with Kissinger in that he doubted that the Soviets would intervene in the conflict and in that he was able to re-establish positive contacts with

28) Graham Allison, "Cold Dawn and the Mind of Henry Kissinger", The Nashington Monthly, March 1974, p. 45 
our Western Exropean allies much easier than Kissinger.

Secretary Schlesinger found that if he was to have a say in the general direction of Anerican national security policy, he would have to becane mare vocal in his coments and perhaps even risk a confrontation with Kissinger. Because Schlesinger's base of support was still quite shallow, he could not risk a showdown with Kissinger. But it is clear that as Schlesinger's prestige grew, and as he became to be seen as a threat to Kissinger's infinence, a potential showdow might occur. A break with Kissinger would have to come on a policy that covered the whole scope of America's attempts to build a positive relationship with the Soviet Union. Detente, and the means by which to preserve it, would be at the center of the controversy. The study of the Kissinger Schlesinger relationship during the period of the October War of 1973 shows that Kissinger's influence would sooner or later be challenged and that detente would most probably be the issue that separated them. 


\section{Chapter VI}

KISSTNGER AND SCHIESINGER: SAIT, DETENTE AND NEGOTIATING STRATEGY

The resignation of Richard Nixon from the Presidency placed former Congressman Gerald $R_{0}$ Ford in the White House. President Ford continued to have Secretary of State Kissinger be the National Security Council advisor to the President. Initially there was some doubt as to whether the President was going to retain Dr. Schlesinger as Secretary of Defense, but by the end of 1974 the President had decided that Schlesinger was to remain as Defense Secretary. ${ }^{l}$

As the year 1975 progressed, a deterioration in the relationship between the two Secretaries was evident, and deep philosophical disagreements about $\sigma_{0}$. national security policy were at the heart of the controversy. The major substantive issue around which this disagreenent came to a head was that of American negotiating strategy with the Soviet Union. In a broader sense, it was the definition of detente and the means by which to preserve it that brought on the schism between the two Secretaries. Both the Congress and the public came to wonder which of the two Secretaries was actually enunciating the policy of the Administration.

The fact that Secretary of State Kissinger dominated the means of access to the President on national security affairs through being the NSC advisor helped to aggravate the crisis, but that in itself was not the cause of the controversy. Charges and countercharges ran through

1) The New York Times, December 29, 1974, p. 13 
the State Department and the Pentagon that tended to show the two departments as antagonists. Eventually the Pentagon released a study that questioned the whole concept of detente, which will be elaborated on in the next chapter.

The problem of analyzing the substantive differences on policy between Kissinger and Schlesinger, and relating them to their own belief systems, is complicated by the fact that the Ford Administration refused to acknowledge the existence of the split. President Ford initially said that the removal of Schlesinger was motivated by a desire to "get his own team", but he later was forced to admit that serious policy differences did enter into his decision to replace $\mathrm{Dr}$. Schlesinger with Donald Rumsfeld. ${ }^{2}$

The substantive differences between Kissinger and Schlesinger conform to the basic models that were developed for each Secretary in the study of their belief systems and perceptions of issues. The means by which to maintain detente was the fundamental issue in the KissingerSchlesinger controversy. Schlesinger maintained that detente could only be perserved through the continuing existence of a strong U.S. military establishment that might have to increase its potential if it was to be a credible deterrent. In this way, argued Schlesinger, the Soviets would not use detente to their own advantage. Kissinger placed less faith in deterrence, because he believed that political issues are best resolved through political processes. Kissinger was disinclined to accept

2) "Ford Finally Admits Tension Led to Shake Up", The New York Times, November 16, 1975, IV, p. 2 
Schlesinger's arguments that the United States should increase its strategic capabilities through technological and targeting flexibility. The major substantive issues on which Kissinger and Schle singer disagreed will be found to center on U.S. negotiating strategy at SALT. The issues to be discussed in this chapter will be:

1) The Cruise Nissile,

2) The Soviet Backfire Bomber,

3) MIRV'S,

4) The Question of Possible Soviet Violations of the agreements.

Other issues that also separated Kissinger and Schlesinger were whether the United States should send Pershing Missiles to Israel, the status of our position on troop reductions at the MBFR talks in Vienna, and on the claim that Secretary Kissinger withheld information from the Pentagon on the Sinai agreement that was negotiated in September of 1975.

Background: The Need to Finalize a SALT II Accord

A very real concern of the Ford Administration was that a SAIT II agreement be reached between the United States and the Soviet Union based on the formulation reached at Vladivostok in November of 1974. Schlesinger's presence and vocal criticism of the tendency of the Soviets to increase the throwreight capacity of their missiles was a contributing factor in the tension that came to the surface between the two Secretaries. The Soviets were concerned that Schlesinger's retargeting policies and his ardent exhortations to keep America's strategic capabilities on a par with the Soviets might mean that American policy was changing away 
fram the previous hannony that had been experienced with President Nixon. ${ }^{3}$ The Soviets also expressed fears that Schlesinger had prepared first strike options that could be utilized in "selective strike" sitnations. The Administration, however, desired to reach an agreement as soon as possible. Schlesinger warned that it would be better if the SAIr II finalization was postponed until after the Presidential election, so that a comprehensive agreement could be reached rather than an artificial one that could be reached very easily and be interpreted ambiguously. 4

The presence of Schlesinger was seen by same observers as the major obstacle to the completion of an arms agreement with the Soviets at SAIF II. 5 In specifics, Schlesinger's presence conplicated possible negotiam tions on the cruise missile, backflre bomber and MIRV's. The American lead in cruise missiles was the primary area of dispute. 6

\section{The Crutse Missile}

The Soviets desired a Ifmitation on the number of cruise missiles that the United States could deploy on Its manned bombers. Defense Secretary Schlesinger was adamantly opposed to negotiating awry the cruise missile advantage, maintaining that it was a "bargaining chip"

3) "Schlesinger Hit for Nuclear War Talk", Current Digest of the Soviet Press, Aug. 6, 1975, p. 3

4) George C. Wilson, "Schlesingerikissinger Schism Deep", The Fashington Post, November 3, 1975, p. 12

5) Joseph Kraft, "The Crumbling Administration", The Washington Post", Novenber 4, 1975, p. 山

6) Dana Adams Schmidt, "FIring Ieaves Kissinger Without Cabinet Challenger", The Christian Science Monitor, November 4, 1975, p. 4 
for the United States. 7 Schlesinger argued that it was impossible to check the number of cruise missiles that both the U.S. and the Soviets had. Secretary Kissinger's position was that the United States might have to limit its deployment of the craise missile as a necessary concession in order to reach a comprehensive agreement. ${ }^{8} \mathrm{Dr}$. Schlesinger's opposition to inclading the craise missile in the 24,00 level limit on strategic delivery vehicles was another point of disagreement. Schlesinger stated that it was not an ICBM because it stayed within the atmosphere when in flight.

\section{The Backfire Bamber}

The possession by the Soviet Union of the backfire bomber was another area of disagreement between Kissinger and Schlesinger. Secretary Kissinger wanted the Soviet backflire bomber to be excluded from the 24,00 strategic delivery vehicle limitation that was agreed to, but $\mathrm{Dr}$. Schlesinger believed that the backfire should be included in the limitation 9 Sehlesinger was also eritical of its exclusion from the strategic delivery vehicle limit because of the fact that the Soviets wanted a limitation put on U.S. cruise missile, and he felt

7) Clarence Ao Robinson, "Cabinet Shifts May Speed SAIr", Aviation Week and Space Technology, November 10, 1975, p. 12

8) The Iondon Economist, November 8, 1975, p. 16

9) The Congressional Quarterly, November 8, 1975, p. 2349 
that to give the Soviets the advantage in both categorles would be unvise. 10 A trade off would have been the more desirable altemative. Secretary Kissinger felt that to limit the backfire, along with a refusal on the part of the United States to consider putting a limit on the cruise missile could lead to a possible breakdown of the negotiations.

It is clearly evident that from the Soviet perception of what was at stake, a Schlesinger removal would facilitate a SAIr II agreement. 17 This perception was to continue throughout the Kissinger-Schlesinger dispute, and the Soviets would not soften their position.

\section{MIRV'S}

One of the most intense points of disagreement between Secretary Kissinger and Secretary Schlestinger was that of the development and counting of the MIRV (Naltiple Independently-Targetable Re-Entry Vehicles) systems of the United States and the Soviet Union. Once again the disagreement shows how K1ssinger was wary of how any new rechnological developments could upset the detente relationship and the status of the negotiations, while Schlesinger was concerned with how technological developments could upset the strategic balance between the superpowers.

The Soviets, according to reports by Secretary Schlesinger, had begun a missile testing program in the sumer of 1973 that demonstrated

10) Tad Szule, "The Firings and Foreign Policy", The New Republic, November 15, 1975, p. 8

11) Gw Halverson, "Schlesinger Ouster Boosts SAIr Prospects", The Christion Seience Nonitor, November 5, 1975, p. II 
that they did possess a $14 \mathrm{RV}$ capability. ${ }^{12}$ Schlesinger belleved that this new development radically changed the overall balance that had been negotiated at SAIT I. ${ }^{13}$ Secretary Kissinger did not, arguing that the United States already possessed a "nuclear sufflciency" that would more than offset any new MIRV technology that was developed by the Soviets. The disagreement centered on the mumber of warheads that the United States should have that would be armed it th MURV's. Secretary Schlesinger believed that the United States should have at least a two to one advantage in ICBM's that were armed with MIRV's because of the fact that the Soviets possessed a decided advantage in the throwreight advantage of its missiles. If Secretary Kissinger dehied that this was a major issue, and repeated his warmings that such demands would only serve to undemine detente and threaten the stability of the international system. Schlesinger at one time was also opposed to an increase in the mumerical limitation on Soviet MIRV's above the level of 1320.15 The method of coumting MIV's was also at issue, with Kissinger favoring possible revisions and Schlesinger opposed to anj change in the counting system.16

12) U.S. News and World Report, May 13, 1974, P. 38

13) "Ford's Costly Purge", Time, November 17, 1975, p. 20

14) Joseph Fromm, "Klssinger-Schlesinger Ferd", U.S. News and Forld Report, July 22, 1974, p. 22

15)Peter Goldman and Thomas DeFrank, "Ford's Big Shuffle, Newsweek, November 17, 1975

16) The London Economist, Novemver 8, 1975, p. 16 


\section{Possible Soviet Violations}

Part of the reason why Secretary Schlesinger was at odds with Secretary Kissinger was becanse of the ambiguity of the SALT I text and the fact that it allowed the Seriets a considerable degree of latitude in the interpretation of the agreement. 17 Fron a technical standpoint, the Soviets had not violated certain provisions of the agrement, but the wording was so loose as to allow for violations of the spirit of the agreement, whcih Schlesinger apparently had decided were quite numerous.

One of the violations of the SALT I agreement that bothered Schlesinger was that of the construction of illegal ICBM silos and up to 200 "conmand and control centers" that had been discovered from the photos given by $0_{0} .5$. intelligence satellites. ${ }^{18}$ Schlesinger was critical of Kissinger in this regard because Kissinger would not present these Fiolations to the Soriets.

One of the violations of the SALT I agreement that was of particular importance in the Kissinger-Schlesinger feud was that of the Soviet testing of radar equipment. The Soviets had begun to place its SA-5 radar on a range on Kamchatka. ${ }^{19}$ The Soviets reportedly had

17) "Schlesinger Hits Violations of SACT, Posture Trend", Aviation Week and Space Technology, December 1, 1975, p. 21

18) Drew Middleton, "Schlesinger's Views of Xissinger Described", The New York Times, Novenver 8, 1975, p. 2

19) Clarence Ao Robinson, "Kissinger Deltberately Concealing SAIT Violations, Zumwalt Claims", Aviation Week and Space Technology, December 8, 1975, p. $\mathbf{W}_{4}$ 
placed testing devices in the modes of their ABM missiles. The testing began in April of 1975 and was to have been used to track incoming missiles. 20 Secretary of State Kissinger later said that it was decided not to bring the radar issue to the attention of the Soviets because the United States did not want to reveal the source of its intelligence. 21 He did not deny that the Soviets used the radar. After his dismissal, Secretary Schlesinger appeared before the Senate Foreign Relations Cormittee and stated that the Soviet radar testing was a direct riolation of the SAIT I agreement. 22

Secretary of Defense Schlesinger's criticism of the SALT I agreement that was negotiated is further demonstrated by the fact that the agreement did not limit the size of missiles that the Soviets could deploy, but only the size of the misșile silos themselves. 23 This was made clear in his criticism of the Soviet deployment of the SS-19 missile, which was fifty percent larger than the anticipated size of Soviet missiles at the time of the signing of the agreement. Since the SS-19 can fIt into the silos of SS-11 missiles, it is technically not a violation of the agreement. Schlesinger remarked that ambiguous agreements that do not account for

20) "Kissinger Answers His Crities", U.S. News and World Report, December 22, 1975, p. 25

21) ibid., p. 25

22) Cecil Browlow, "Soviet Weapons Work Seen as SAIT Violation", Aviation Week and Space Technology, December 8, 1975, p. 16

23) Clarence Ao Robinson, "Cabinet Shifts May Speed SAIT", Aviation Week and Space Technology, November 10, 1975, p. 12. 
circumstances such as these were part of a Kissinger strategy of negotiating "Pre-emptive concessions" to the Soviets. $2 \mathrm{l}_{4}$

Despite the Schlesinger criticism of the SALT I agreement, the Defense Secretary still believed that a SALT II agreement should be reached. But Schlesinger's criticism of the Kissinger negotiating style does show that each Secretary had a fundamentally different perception as to what is negotiable and what is not. The examination of Schlesinger's criticisms of Kissinger on SAIT negotiating strategy prove that he belleved that military advances made by the Soviet Union must be analyzed comparatively rather than on their own merits. Only one that prevents the Soviet Union from gaining advantages fran a loose interpretation of the agreement can be acceptable to 8.5 . national security decision makers. Secretary Kissinger believed that the strict enforeement of a SALT agreement and a demand for concessions on the part of the Sorlets on the backfire borber could make the Soviets decide to leave the negotiating table and resume an unending arms race. These positions are directly related to each man's bellef system and his perception of what is at stake in strategic ams limitation negotiations.

\section{Kissinger's Control of Information}

Kissinger's dominant role as both Secretary of State and National Security Council advisor to the President was of increasing importance as the policy disagreements betwen Kissinger and Schlesinger became apparent to 2 ll by 1975. Secretary Schlesinger's most revealing conment

24) Drew Middleton, "Schlesinger's Views of Kissinger Described", The New York Times, Novenber 8, 1975, p. 2 
as to Kissinger's deminance was that the Secretary of State would often "throttle debate" and fail to bring to the President policy recommendations and opposing points of view from Schlesinger and other NSC members. 25 Kissinger and Schlosinger were said to have engaged in heated debates over ams negotiating strategy at many of these NSC meetings. 26

Secretary Schlesinger was also disturbed by the fact that Secretary Kissinger did not inform the Pentagon as to the September 1975 negotiations on the Sinai agreement. 27 Whether or not Secretary Kissinger had come to make a habit of not informing other govermment officials as to the status of negotiations and agreements has been a topic of consider able debate in this country, especially the charge that he kept President Ford in the dark as to possible Soviet violations of the SALT I and ABM agreements. 28 In any event, the tendency of Kissinger to centralize the channels of cormunication to the President forced Secretary Schlesinger to becone more vocal in his criticisms of American negotiating strategy.

\section{Conflict over the Pershing Missile}

Secretary of State Kissinger and Secretary of Defense Schlesinger also disagreed on whether the United States should provide Israel with

25) "Ford's Costly Purge", Time, November 17, 1975, p. 12

26) "Detente: H.K. I J.S.", Time, November 17, 1975, p. 20

27) Bernard Guertranan, "Behind Shift: Push for Arms Pact", The New York Times, November 4, 1975, p. 1

28) R. Hotz, "The Case Against Kissinger", Aviation Week and Space Technology, December 8, 1975, p. 7 
Pershing Missiles. 29 Kissinger wanted to give the Israells the means by which they could defend themselves in the event of another Arab attack and maintain the semblance of a balance of power in the Middle East. Secretary Schlesinger, while acknowledging the importance of a military equilibrium in the Middle East, saw the providing of Pershing missiles to Israel as sanething that could deplete the U.S. stockpile of that missile, since the United States had stopped its production. 30 Schlesinger was cancerned about the effect that this would have on U.S. defense capabilities, just as Kissinger was concerned with the impact that a revelation of our knowledge of Soviet radar violations would have on our ability to get intelligence about such violations in the fature. In each case the Secretaries.disagreed, but the motivation for the disagreement was the same.

\section{The Forward Based Systems-FBS}

Another issue that separated Secretary Kissinger and Secretary Schlesinger was that of the place of the Formard Based Systems in muclear arms limitations. The Forward Based Systens are nuclear equipped aircraft and missiles that are based in Europe. Secretary Kissinger wanted to keep the FBS out of the SAIT negotiations and put them in the Nhtual Balance and Force Reductions talks at Vienna. Secretary Schlesinger

29) Dana Adans Schmidt, "Firing Ieaves Kissinger Without Cabinet Challenger", The Christian Science Monitor, November 4, 1975, p. 4

30) Clarence A. Robinson, "Cabinet Shifts May Speed SALr", Aviation Week and Space Technology, November 10, 1975, p. 12 
disagreed, saying that the FBS should be put in the SAIF document. 31 Here again is an example of a policy disagreement that helped to set the two Secretaries at odds with one another.

\section{The Inevitable Policy Confrontation}

From a study of the disagreements between Secretary of State Henry Kissinger and Secretary of Defense James Schlesinger it is clearly evident that both men disagreed on what the arms negotiating polficy of the United States should be. These disagreements were generated out of differences as to their perception of the Soviet threat and their definition of what constitutes a threat to the national security of the United States. Schlesinger insisted that the United States maintain a position of superiority in the negotiating sessions, and was inclined to favor a relatively hard line stance towards the Soviets. 32 Not only did Schlesinger believe that the United States should not make any concession to the Soviets, but he also took the position that it should be the Soviets who should be making the concessions. 33 Kissinger's fear was that a prolonged use of a strategy such as Schlesinger was advancing could lead the Soviets to believe that it was the United States that was trying to use detente to gain a strategic advantage, and thereby lead to

31) The Economist, November 8,1975, p. 16

32) "Further Fallout From the Shake Up", Time, November 24, 1975, p. 29

33) John Finney, "Uncertain Pentagon Asks What Rumsfeld's Policy Is", The New York Times, November 5, 1975, p. 24 
a deterioration in the negotiations. ${ }^{34}$ Kissinger's emphasis on actions of decision makers are important in this regard. The actions of the leaders of the United States should be cooperative and conciliatory, and attempts to gain an advantage over the Soviets in arms limitations negotiations could lead to a breakdom in the detente relationship.

The desire of Kissinger and President Fart to obtain a SAIT II agreement in an election year faded after the removal of Dr. Schlesinger from the Pentagon. The Soviets saw Schlesinger as an obstacle to a new SALT accord. ${ }^{35}$ While President Ford stated that he was under no timetable to reach an agreement with the Soviets, in January of 1976 he sent Dr. Kissinger to Moscow to confer with Breshnev and Kosygin on SAIT II, and the White House reported that the President had reached an agreement within the Administration on a conpromise proposal for SALI II. ${ }^{36}$ such a proposal might have been resisted by Schlesinger. The Soviets, ever wary of the impact the Presidential campaign on American negotiating strategy, began to stall on the U.S. proposals because of the internal debate over detente in the United States. With Secretary of State Kissinger coming under vicious attack from the anti-detente forces in the United States, President Ford was forced to reconsider the effects that a SAIT II agreement might have on the Administration and its conduct of foreign and defense poliey, and decided not to pursue SALT II any further

34) "Pentagon: A Strong Voice is Stilled", U.S. News and World Report, November 17, 1975, p. 17

35) Peter Osnos, "Kremlin Saw Defense Chief as Foe", The Washington Post, November 4, 1975, p. I

36) The New York Times, February 17, 1976, p. 18 
this year. 37 The firing of Schlesinger opened up a new round of criticism of Secretary Kissinger and President Ford, and instigated a debate in this country over Kissinger's negotiating strategies and the benefits of detente. The result was the postponement of the SALT II agreement.

The need for a President to surround himself with individuals of opposing points of view is necessary in any administration. But once a policy has been decided upon, there is a need to unite behind it if it is to be successful. A failure to accomplish a push towards accomodation on a policy decision, according to former Johnson Administration aide Roger Hilsman, can lead to a breakdown in the system of policy making itself:

"... there is in all participants an intuitive realization that prolonged intransigence, stalemate and indecision on urgent and fundamental issues might become so intolerable as to threaten the very form and structure of the system of governance". 38

It is the responsibility of the President to maintain an organization that can inform him as to the problems that are present in the making of American national security policy. The President should encourage an adversary relationship between his Cabinent members and advisors in the formulation of policy, but it is imperative that unanimity be present if its execution is to be effective. If conflicts cannot be resolved, participants in the decision making process eventually may try to alter or change the rules by which decisions have been

37) The New York Times, April 12, 1976, p. 1

38) Roger Hilsman, The Politics of Policy Making in Defense and Foreign Affairs, (Harper and Row: New York, 1971) p. 117 
made. 39 If this becomes evident to the President, he will be put into the position of choosing between rival policies. If the Secretary of State is involved, one would expect that the President would adhere to the advice of the Secretary of State, because the relationship between the President and his foreign secretary is the most important one in the making of American foreign policy. 40

Secretary Kissinger's dominance in the national security decision making process made it difflicult for Secretary Schlesinger to get his alternatives to the President in a form that would present cogent rebuttals to the Kissinger proposals. At least that was the Schlesinger claim. This combined with the serious policy differences on detente, SAIT negotiating strategy and the issue of Soviet violations of past agreements led Schlesinger to publicly disagree with many Administration policies. Schlesinger decided to risk the wrath of the President, and contimued his criticisms, along with open comments on the irresponsibility of the Congress. Schlesinger had been known to want to use his office to "stimulate a great debate about American defense policies". 47 This is perhaps the motivation for his candor. Soon the disagreements would become so intense that the President would have to choose which man would stay and which would go.

39) Morton H. Halperin, Bureaucratic Politics and Foreign Policy, (The Brookings Institution: Washington, D.C., 1974) P. 104

40) ibid., p. 17 .

47) Ieslie H. Gelb, "Schlesinger for Defense: Defense for Detente", The New York Times Magazine, Angust 4, 1975, p. 35 


\section{Chapter VII}

KISSINGER AND SCHLESINGER: THE DIA REPORT AND THE DEFENSE BUDGET

The division within the Ford Administration on national security affairs was exacerbated by the release of a repart by the Defense Intelligence Agency that questioned Soviet motivations for pursuing detente. The report, released just a few days before the firing of Secretary of Defense Schlesinger, had angered Secretary of State Kissinger to such an extent that he blamed Schlesinger for its release. After this incident the decision making point became inevitable for President Ford. The President would have to decide whether it was possible to coordinate foreign and defense policy under circumstances such as these.

Secretary of State Kissinger was angered by the fact that the DIA document had been allowed to clrculate throughout the Department of Defense, and eventually reach the hands of an outside, private organization, the American Security Council. ${ }^{1}$ The American Security Council is a conservative organization that is known to be skeptical of the detente policy with the Soviet Union and is highly critical of Secretary Kissinger's policies in general. The report was released to the American Security Council in October of 1975, and the major responsibility for its release appears to be with both Lieutenant General Daniel 0. Graham, the Director of the DIA, and former Secretary of Defense Schlesinger.

1) Joseph Kraft, "The Crumbling Administration", The Fashington Post, November 4, 1975, p. I4 
The report was worded in a manner that would cause either President Ford or Secretary of State Kissinger to wonder if the Pentagon was in the process of undermining the foreign policy objectives of the entire Administration. The major thrust of the DIA report is well established by the statement in it that,

"For the Soviets, detente is intended to facilitate their
attainment of overall dominance of the West... in the U.S.
detente tends to be seen as an end in Itself, in the U.S.S.R
it is seen as a strategy for achieving broader Soviet objec-
tives as well as tactical aims without fueling the sorts of
concerns that might galvanize the West into serious counter-
action."
"Soviet long term strategic objectives, which the detente
strategy seeks to promote include:... the establishment of
Soviet political, military, technological and economi super-
iority worldwide. Soviet detente strategy has facilitated
Soviet strategic expansion and the cancelling out of U.S.
superiority without provoking extensive Western counter
efforts." 2 .

The DIA report continued to question the motivation of the Soviets in pursuing strategic arms limitation agreements, and specifically stated that the policy of detente had served Soviet purposes well and that because of that, the Soviets would not discard it but try to use it to gain other advantages over the United States. The DIA report specifically said that,

1) The long range goal of the Soviets was to break up the Western Alliance and force a U.S. military withdrawal from Europe,

2) "Detente in Soviet Strategy", an Estimate by the Defense Intelligence Agency, Department of Defense, September 2, 1975, reprinted in the Washington Report (October 1975) p. 1 of the American Security Council 
2) Detente has encouraged further Soviet nuclear arms expansion,

3) Soviet nuclear expansion has forced the United States to try to accomodate the Soviet Union through concessions at the strategic arms limitation negotiations,

4) The end result of these developments has been to neutralize the technological advantage of the United States,

5) The Soviet Union is trying to isolate Communist China until nerr leadership cames to power after the death of $\mathrm{KaO}$,

6) The Soviet Union is still prepared to exploit any crisis that might arise in any area of the globe,

7) The Soviets will eventually discard detente if they can gain more by other means. 3

The DIA report went even further in its criticism of American negotiating strategy. in saying that,

"In strategic weaponry, Soviet detente policy has created a climate that has facilitated SAIT agreements under which the U.S. was prepared to freeze force levels but allow the Soviets to build numerical parity..." 4

The American policy, according to the report, along vith Soviet strategic nuclear expansion, allowed the Soviets to achieve a force structure that neutralized America's qualitative superiority. The effect that the report had on the State Department and Secretary Kissinger in particular was to create doubts in their minds as to

3) "Detente Study Feuled Kissinger-Schlesinger Feud", Aviation Week and Space Technology, November 10, 1975, p. 13

4) ibid., p. 13 
whether the Pentagon would support any future negotiations with the Soriets on SAIT II. Such divisiveness could only hurt the prospects for a new arms limitation agreement with the Soviet Union. President Ford was faced with a decision that couid trigger enormous hostility towards his administration no matter what his decision was.

The Ford Administration was divided against intself on national security, issues of the highest importance. Differences of opinion that were long in the making came to a crossroads in which an evaluation of the strengths and weaknesses in continuing this arrangement had to be taken into consideration. With the State Department being accused of not giving the Pentagon all the information that it requested on the substance of the Sinai negotiations, and the Secretary of State having previously not consulted with the Pentagon on the assurances that the U.S. gave Israel that it would consider giving them Pershing missiles, the groundwork had already been laid for a relationship that could become increasingly tense and hostile. 5 Tensions were made worse by the continued domination by Secretary Kissinger of the means of access to the President on issues of national security by virtue of being NSC advisor to the President. With the substantive differences of opinion between both Secretary Kissinger and Secretary Schlesinger over SAIT, the cruise missile, the backfire bomber and MIRV's, it is little wonder that Schlesinger and the Pentagon would come to the point where they appear to be openly forcing a decision on the part of the

5) Bernard Guertrman, "Behind Shift: Push for Arms Pact", The New York Times, November 4, 1975, p. I 
President on the future of American national security policy. With the release of the DIA report in October of 1975 , what can be seen is that the Administration was divided, and that the State and Defense Departments were openly hostile to one another.

President Ford could not tolerate this situation much longer. To fire Schlesinger would lose him the political support of conservative Republicans and Democrats and would fuel the anti-detente lobby with more evidence of the fact that Kissinger was too powerful in the Administration. Ijberals would express the fear that Kissinger was without an opponent of his own stature in the Administration, who while not in agreement with their own philosophies, could at least provide a check to Kissinger's influence. To remove Kissinger would undermine Ford's foreign policy in the eyes of the rest of the world, and would cause the Soviets to wonder if the United States was about to revert back to the policies of the Cold War. The Soviet perception of Schlesinger as a hard liner and an advocate of "counterforce" nuclear strategies that could upset the status of detente should not be discounted as a possible reason for the Schlesinger removal. The Soviet fear that detente was losing support among the American people was a major reason for the inability of the United States and the Soviets to reach an agreement on SALT II. The Schlesinger removal could have made this easier from this perspective. The irony is in that the Schlesinger removal increased the detente debate within the United States and forced the President to reconsider his position on SALT II, fearing that concessions made by the United States would further damage his forelgn and defense policies in an election year. 
Secretary of Defense Schlesinger worsened his already tenuous position in the Administration when he outspokenly criticized the Congress and the Administration for cuts in the defense budget. This was not the primary reason for the removal of Schlesinger, but it did provide the Administration with an excuse to remove Schlesinger and domplay the importance of the differences between Schlesinger and Kissinger on SAIT and detente. The defense budget issue is important in that Secretary Kissinger also wanted to keep defense spending at as economical level as possible because he feared that increase in armaments and military spending would come at the expense of detente. 6

Secretary Schlesinger's actions continued to be a source of discomfort for the Administration and President Ford. On October 20th the Secretary held a news conference that criticized the House Appropriations Committee for making cuts in the defense budget that were described by the Secretary as "deep, savage and arbitrary".7 The cuts would have amounted to $\$ 7.6$ billion from the proposed $\$ 97.8$ billion budget requested by the Administration. ${ }^{8}$ Schlesinger himself wanted a $\$ 13.7$ billion increase in defense spending for Flscal Year 1976.9 President Ford, as

6) Joseph Framm, "Kissinger-Schlesinger Feud", U.S. News and World Report, July 22, 7974, p. 22

7) John McNaughton, "The Ford Upheaval and Some Explanations", The New York Times, November 6, 1975, p. 14

8) "Ford's Costly Purge", Time; November 17, 1975, p. 17

9) The Congressional Quarterly, November 8, 1975, p. 2349 
a minority President who was not elected, could ill afford poor relations with legislative branch that would have been heightened if Schlesinger had continued his attacks. Schlesinger's concern over Soviet increases in its defense budget and military manpower have been previously refered to. (See Chapter III pp. 22-23).

Secretary Schlesinger was also highly critical of the Administration's proposal to cut the defense budget for Fiscal Year 1977. The Office of Management and Budget had proposed an $\$ 8$ billion cut in the Defense Department's budget for FY 1977. ${ }^{10}$ President Ford's desire to keep the total budget down was obviously a major factor in the ONB proposal. Secretary of State Kissinger had always believed that U.S. defense policy should be made mindful of the effects that increased budgets would have on the condact of foreign policy and the impression it would give to the Soviet Union. Because Schlesinger was advocating an increase in the defense budget, and it has already been demonstrated that the great majority of U.S. defense spending accounts for military pay compensation and pensions, the increases that Schlesinger ras requesting could only come in the area of strategic weaponxy and conventional weaponry. Kissinger was uneasy th Schlesinger's statements about the need to increase military spending in order to match that of the Sovlets because he belleved that this would hurt his efforts to reach 2 second arms control agreement with the Soviet Union. ${ }^{11}$ The issue of the

10) The Congressional Quarterly, November 8, 1975, p. 2349

II) ibid. p. 2349 
defense budget was not anly an area of disagreement between Schlesinger and the President, but also one that had ramifications that concerned the Secretary of State. SALT and the comparative Soviet-American stram tegic ans balance were once again at the center of the issue.

Schlesinger himself is reported to have said that a second SALT agreement could have been negotiated by kissinger during Jane of $1974 .{ }^{12}$ Kissinger was blamed by some technical experts for ordering Secretary Schlesinger not to submit position papers written by the Joint Chiefs of Staff in Connection with the July 1974 sumit for then President Nixon's consideration, 13 Both the JCS and Schlesinger wanted to press the Soviets for more concessions on malear missiles than Kissinger believed was negotiable at the time. The issue of defense budgeting on arms negotiations was undoubtedly another example of how Kisainger and Schlesinger differed on arms negotiating strategy with the Soviet Union.

Was Schlesinger forcing the is sue before the consideration of the President? His dissent from the Administration's policies were only part of the reason why an inevitable Kissinger-Schlesinger feud came about. His inability to fudge the political consequences of national security decisions and his own concern with the substance of the issue flts his own non-rational model of decision making that is more concerned obtaining the best alternative in policy decision making rather than the

12) Iesli $\mathrm{H}_{0}$ Gelb, "Schlesinger for Defenses Defense for Detente", The New York Times Hagazine, Angust 4, 1974, p. 43

13) R. Hotz, "The Case Against Kissinger", Arlation Week and Space Technology, Decenber 8, 1975, p. II 
most acceptable one for all parties concerned.

A serious dispute was to emerge between the State Department and the White House on the one hand and the Pentagon and Secretary Schlesinger on the other in the last days before Schlesinger's removal as Defense Secretary. The White House accused Schlesinger of having leaked to the press the disagreements that he had with Secretary of State Kissinger over troop deployments in Burope. $\mathcal{H}_{4}$ There was no substantiating evidence to back this charge. In the Pentagon, aides to Secretary schlesinger were afraid that the White House and the State Department were trying to weaken Dr. Schlesinger's role as a counter to Kissinger on national security affairs. The Schlesinger aides saw the removal of Dr. Schlesinger as the result of a "State Departinent campaign aimed at weakening Schlesinger's position". 15 The antagonisms that were noticeable between the two Secretarles over SAIT II, Sovlet violations of the SAIr I and ABM agreements and the defense budget caused Kissinger to come to see Schlesinger as a rival who would threaten his policies and negotlating strategies, which was a complete change fron Kissinger's perception of Schlesinger in $19740^{16}$ Whether Schlesinger actually was a threat to the success of a SAIT II agreement will never be known, but his

14) Rowland Evans and Robert Novak, "Intolerable Dissent", The Washington Post, November 6, 1975, p. 27

15) Drew Kiddleton, "Schlesinger's Views of Kissinger Described", The New York Times, Novenber 8, 1975, p. 2

16) "Schlesinger on Defense", Aviation Week and Space Technology, October 21, 1974 , p. 9 
removal only served to force the Soviets to rethink the wisdan of negotiating with a United States that was internally divided over the wisdom of detente.

The decision on the part of the President to ask for Secretary Schlesinger's resignation came suddenly and without waming. Part of the reason for this is because the vast majority of the public and even the Congress, intellectual establishment and the media was not aware of the internal division within the Adninistration that is typifled by the DIA report. President Ford's statement that "neither policy nor personal differences" were involved in the Kissinger-Schlesinger feud cannot be taken seriously. The President was faced with an embarrassing situation that gotten out of control, and was attempting to deny his past mistakes by refusing to admit that the substantive policy differences between Kissinger and Schlesinger had divided his Administration. Eventually the President was forced to admit that there was an antagonism that existed between Kissinger and Schlesinger, but by that time his credibility had been badly damaged. 17

The policy confrontation that evolved in the Ford Administration between Secretary of State Henry Kissinger and Secretary of Defense James Schlesinger was one that was made inevitable because of their differing theoretical conceptions of the international system, the rature of power in the nuclear age and the importance of detente as a stabilizing factor in the relations between the United States and the Soriet Union. The seriousness of the pollcy confrontation was felt

17) "Ford Finally Admits Tension Ied to Shake Up", The New York Times, November 16, 1975, Part IV, p. 2 
throughout the Ford Administration. 18

The differences of opinion on substantive issues between Kissinger and Schlesinger can be traced to their conceptions of powrer and the decision making process in national security affairs. Kissinger's rational model of decision making places greater emphasis no negotiation of differences, the complexity of military power and the importance of macropolitics. Kissinger's conception of "legitimate" and "revolutionary" international systems best explains his belief that the Soviets are now status quo oriented powers, concerned with preserving the gains that they already have made. His concern for the reduction of tensions, a reduction of the development of new weapons technologies, and for international cooperation gives him a different definition of what is the national security than does Dr. Schlesinger.

Schlesinger's faith in deterrence and the need for a preservation of the military equilibrium between the United States and the Sorlet Union shows a different motivation than that of Dr. Kissinger. For Schlesinger, detente is made possible because of "an underlying equilibrim of force".19 The Soviet desire for a reduction in tensions does not plig as great a role in his development of a rationale as to why "detente" is the present state of relations between the two superpowers.

The disagreements between Kissinger and Schlesinger over detente is perhaps best demonstrated by the fact that Schlesinger himself

19) James Ro Schlesinger, "Weakness Invites Conflict", Vital Speeches of the Day, October 15, 1975, p. 2 
reanimed highly skeptical over Soviet motivations for pursuing detente. Far fram becoming a status quo oriented power, the Soviets, in Schlesines's vier, do not wish to postpone national liberation movements andwars of liberation, but instead wish to increase the ideological straggle between the superpowers. Schlesinger states that,

"In the Soviet view, detente itself is the consequence of the outgrowth of Soviet power, which has forced the West to grant concessions.... Far from sharing the Western view of detente as gradual reconciliation, with the hope of ending the possibility of conflict, the Soviets view detente as rich with opportunities for major gains--in short, 2 s confrontation in another guise". 20

with two opposing philosophies such as these it should be reibuted that the two Secretaries did not disagree on whether deterte exists, but over the meaning of it. If detente means that the Irited States can reduce its commitments around the world and drantically reduce its defense budget, then the definition of the national security has also been dramatically changed. How will an Amentican President ever justify sending U.S. troops into combat in an efrort to "contain" Commanism, as in Korea and Vietnam, if the Sovizs are now a status quo power? Do potential liberation movenents in Africa and South America have no importance to the U.S. national security? Abote all, does detente mean that the United States can wither into a period of neo-isolationisn, being totally concerned with its own domestic problems, while neglecting the problems that face the world at the international level? The answers to these questions,

20) James $R_{0}$ Schlesinger, "A Testing Time For America", Fortune, February 1976, p. 147 
and to the reasons for the Kissinger-Schlesinger controversy in the Ford Administration must lie in an analysis of the nature of the international systen, the ability of nations to use power to influence or deter other nations from exhibiting certain kinds of bekavior and in the process by wich national security decision makers develop policies that should be followed if peace is to be preserved. 


\section{Chapter VIII}

\section{KISSINGER AND SCHUESINGER: FOREIGN AND AMERICAN FEACTI ON}

The interest with which the nations around the world viewed the Kissinger-Schlesinger controversy should not be overlooked. For it establishes the intensity of the two Conmunist giants reactions to the controversy and also the doubts that our NATO and West European allies had as to the strength of the American commintment to their defense. It shows once again that the perceptions of nations as to the foreign and defense policles of the United States is in large measure influenced by the individuals who man the decision making positions in national security affairs. Policy alone is not sufficient. Policy differences, as ware seen, can be so intense that foreign nations will be confused as to what American policy actually is. The reactions and perceptions of nations to the Kissinger-Schlesinger controversy will gh ow that this incident was of great interest to the international community, specificcally, the Sorlet Union.

\section{Soviet Reaction}

The Soviet Union was delighted with the removal of Secretary Schlesinger from his position, as could be expected from the fears about him that were voiced in the past. The Soviets corroborate the findings of the author that the disagreements between Secretary Kissinger and Secretary of Defense Schlesinger had boen centered on detente and the strategic arms Iimitation negotiating strategy, of the United States 
with the Soviet Union. ${ }^{1}$ The Soviets are also to have reported that the Atlantic Community and supporters of NATO would miss the politician who tirelessly warned of the Soviet threat" ${ }^{2}$ In the eyes of the Sovlets, the dismissal of Secretary Schlesinger was seen as a victory for detente and the policies of the Ford-Kissinger Administration.

The Soviets had been following the Kissinger-Schlesinger feud closely for more than one year. ${ }^{3}$ The Soviets regarded a victory by Kissinger as essential if the detente relationship between the United States and the Soviet Union was to continue. The great majority of the study that was done by the Soviets on the Kissinger-Schlesinger feud was done by specialists at the Kremlin think-tank, the USA Institute for International Relations and World Econonics. 4 The Institute followed the differences on policy between Kissinger and Schlesinger for over a year, and came to the conclusion that Kissinger's approach to bargaining with the Soviet Union was endangered by the presence of Schlesinger in the Administration. They naturally warmly endorsed the move by President Ford to dismiss Schlesinger.

The Soviet news agency TASS reported that the editor of the Soviet magazine USA-Economics, Politics, Ideology, Valentin Berezhkov, welcomed

1) "Shake Up in Washington", Current Digest of the Soviet Press, November 26,1975 , p. 23

2) Current Digest of the Soviet Press, December 10, 1975, p. 21

3) Peter Osnos, "Krenlin Sam Defense Chief as Foe", The Washington Post, November 4, 1975, p. 1

4) "Personnel Changes Cause Strong Repercussions", Peking Review, November $I_{4}, 1975$, p. 20 
the Schlesinger dismissal in calling it "a positive development between the superpowers" $0^{5}$ One could conclude that the harsh Soviet criticism of the Schlesinger retargeting policies, calls for increases in the defense budget, and hard line approach to strategic arms limitation negotiations with Soviets were the primary reasons for their approval of Ford's decision to replace Schlesinger. Whether Schlesinger actually was an impediment to an improvement in Soviet-American relations is debatable, but the Soviet reaction to his removal does demonstrate the importance of the Kissinger-Schlesinger incident and the diligence with which the Soviets studied the individual differences between the two Secretaries.

\section{Conmunist China's Reaction}

The Communist Chinese were dismayed by the firing of Secretary Schlesinger, fearing that the United States had succumbed to the pressures for easy concessions to the Soviet Union in future arms limitation agreements negotiations. Quotes from the Chinese international news digest Peking Review of foreign reactions to the firing are entirely negative. Peking Review stated that the West Germans were "stunned" by the firing, that the loss of Schlesinger would be detrimental to the NATO alliance and that the French paper France Soir stated that Schlesinger "was sacrificed on the altar of detente" ${ }^{6}$ The Communist Chinese were concerned that the detente relationship between

5) ibid., p. 19

6) ibid., p. 20 
the United States and the Soviet Union was being carried too far, and that they would eventually become the victims of the relationship.

An analysis of the Soviet and Chinese reactions to the KissingerSchlesinger incident shows that the two Communist giants still hold a great deal of animosity towards one another. The Chinese are fearful that the "American connection" that had been established by President Nixon was beginning to weaken. The Chinese response to the Schlesinger firing was one that was wary of Soviet motivations for pursuing detente, and they saw Schlesinger as a possible ally in this regard. The Soviets sided with Kissinger in the controversy, and had nothing but negative remarks for Secretary Schlesinger.

\section{West German Reaction}

The West Germans had favored Secretary Schlesinger's policies on the need not to sacrifice defense spending and preparedness for the sake of detente. 7 In particular, West German Defense Minister Georg Leber was an ardent Schlesinger admirer. The West Germans analyzed the incident in much the same way as did the Soviets and the Chinese. Schlesinger appeared to be an obstacle to a successful completion of the SAIT II agreement, but West German opinion was divided as to whether the United States would profit from a Kissinger diplomatic victory with the Soviets at SAIF II. 8 One West German analyst commented on the fact that Kissinger

7) Bernard Weintraub, "Nato Reported to Feel it is. Losing Strong Ally", The New York Times, November 4, 1975, p. 25

8) Atlas, December 1975, p. 6 
"Unlike Schlesinger, is prepared to bring in the technological advantage of the cruise missile, the guided missile that can strike at military targets by ducking under radar screens to the nuclear exchange deal".

Defense Ninister Leber's good relationship with Schlesinger was undoubtedly a reason for his sorrow at Schlesinger's dismissal. It should be remembered that Schlesinger and Ieber worked out an agreement during the weeks after the 1973 October War that provided that U.S. military equipment would not be sent from West Germany to Israel on Israeli ships. Kissinger's poor relations with the Europeans at that time most probably was remembered by the West Germans as they considered the impact of the Schlesinger removal.

\section{Great Britain, France and Italy}

Other European reaction to the removal of Dr. Schlesinger showed a concern over the strength that Secretary of State Kissinger would now have in the making of American national security policy in the Ford Administration. From Great Britain, it was commented on that Secretary Kissinger would now have a free hand in the making of arms limitation agreements with the Soviet Union. 10 Even when Dr. Schlesinger was admonished for his defense policies and desire to increase the technological capabilities of America's nuclear forces, he was praised in that he provided Kissinger with a countercheck to make sure that the "price of

9) "Ford Shows Strength in Halloween Massacre", The German Tribune, November 16,1975, p. 3

10) The Iondon Times, November 5, 1975, p. 15 
detente was not too high". 11

The London Times oited Secretary Schlesinger's desire to develop the cruise missile and the B-I bomber as reasons why he was considered an obstacle by the Soviets to another attempt to conclude the SALT II accords. ${ }^{12}$ Kissinger's wide acceptance on the part of the international community was seen as important in the decision to remove Schlesinger, because of the fact that the removal of Kissinger would have jeopardized the stability of American foreign policy at a time when stability was absolutely necessary.

The Italians and the French both expressed the belief that Schlesinger's removal would ease the way for Secretary Kissinger to negotiate a compromise at the SALT talks. ${ }^{13}$ Their insight into the the origins of the Kissinger-Schlesinger feud suggests that all West European nations not merely the West Germans and the British, were cognizant of the differences between the Secretary of State and the Secretary of Defense that divided the Administration on national security matters. The reaction of the European nations shows that there was a concern over the future of American policy, and that. the removal of Schlesinger apparently removed any doubts in their mind as to what policies the United States would follow. Kissinger, however, was still the subject of criticism, and the Europeans feared that his influence could become too strong.

17) ibid., p. 15

12) The Iondon Times, November 4,1975, p. 5

13) Atlas, December 1975, p. 6 


\section{Japanese Reaction}

The Japanese reaction to the removal of Secretary Schlesinger was mixed. The Japanese were more inclined to see politics as the motivation for the Schlesinger removal, but they did express concern that the United States was weakening its commitments in the Far East. Secretary Schlesinger had been an important partieipant in the promotion of US-Japanese relations and mutual understanding. ${ }^{1 / 4}$ Schlesinger's reiteration of the American defense commitment to South Korea was probably a major factor in the Japanese expression of concern. While the Japanese tended to discount the belief that Schlesinger's removal was a victory for Secretary Kissinger, they did state that "there will be a need for reassurances in this part of the world" that the United States would retain a strong defense posture after the removal of Schlesinger. ${ }^{15}$ Whether the Japanese were fearful that the United States would abrogate its responsibilities to the Japanese was not clear, but the Japanese did remind the Americans that the United States-Japanese Security Treaty was still" a basic U.S. policy". 16

\section{The Mdddle East}

The impact that the removal of Secretary of Defense Schlesinger had on Israel and Egypt was different, as one could expect. The Israelis, in spite of the delays that they experienced with the United

I4) Atlas, December 1975, p. 6

15) The Japan Times, November 6, 1975, p. 12

16) Atlas, December 1975 , p. 6 
States over the resupply crisis in the October War of 1973, were concerned that the removal of Schlesinger would make it harder for them to get weapons from the United States. The Tel Aviv paper Yedioth Ahronoth was particularly concerned over the impact that the Schlesinger removal would have on future weapons procurements from the United States. 17 If Schlesinger was responsible for the resupply delays as was suggested, it is certainly ironic that the Israelis would be concerned about the effect of his removal as Defense Secretary would have on their ability to obtain arms from the United States. The Egyptians, aware of Schlesinger's criticism of the Soviet Union during the 1973 October War and his cooperation with Kissinger in the implementation of the worldwide alert of U.S. forces, had a different reaction to his dismissal. The Egyptians were reported to be delighted with his removal. 18

The Reaction of NATO

The reaction of NATO to the Schlesinger firing was greatest among all organizations concerned with American cooperation with defense partners. Schlesinger had always been highly regarded at NATO and by European defense officials for favoring a strong Atlantic Alliance and defense preparedness for Europe. His opposition to the unilateral withdrawal of American troops from the European continent was a primary

17) Nichael Getler, "Defense Shift is a Jolt to Bonn, NATO", The Washington Post, November 3, 1975, p. If

18) The Iondon Times, November 4, 1975, p. 5 
reason for their admiration of the Defense Secretary. Schlesinger had the trust of the NATO officials because of his authoritative comnand of the subject of military strategy, his ablility to make quick decisions and his ability to give the NATO defense ministers the philosophical arguments to reinvigorate the NATO community. 19 NATO officials were especially concerned that the new U.S. Defense Secretary, Donald Rumsfeld, was a novice in the area of defense affairs and did not have Schlesinger's expertise. 20

The NATO concern was one of how strong the American defense commitment towards them would be after the removal of Secretary Schlesinger. The Western Europeans and the NATO officials, as might be expected, were concerned that Kissinger would come to dominate the making of American defense policies towards Europe and NATO now that Schlesinger was out of the picture. The cordiality with which AmericanNATO relations had been conducted during the tenure of $\mathrm{Dr}$. Schlesinger as Defense Secretary were now subjected to new inputs that made European officials wonder as to the strength of the American commitment to their defense.

An Analysis of Foreign Reaction

An analysis of the foreign reaction to the Kissinger-Schlesinger incident shows that the forefgn nations had a good grasp of the

19) Bernard Reintraub, "NATO Reparted to Feel it is Iosing Strong A]ly", The New York Times, November 4, 1975, p. 25

20) ibid., p. 25 
substantive issues that were the cause of the incident, but that they did not have a clear insight as to how far the Ford Administration had been divided against itself over detente and the intensity of the mistrust that was alluded to in the release of the DIA report to the American Security Council and the accusations by both the State and Defense Departments about the attempts by the other department to undermine their Secretary's influence with the President was not mentioned, perhaps because of the fact that these accusations were not made public until after the removal of Secretary Schlesinger.

The Soviets, in particular, had a keen insight as to the theoretical and substantive differences that separated Kissinger and Schlesinger. The Soviets had been studying these differences for over a year, and concluded that the removal of Secretary Schlesinger would be in their own interests. But the reaction to the Schlesinger firing in the United States set of a debate over detente policy with the Soviet Union that entered into the Presidential primary campaign and ultimately led to a postponement of the SAIT II agreement. The Sovlets decided to await the outcone of the debate within the United States and would not accept the compromise proposals offered by Secretary of State Kissinger. The flring of Secretary of Defense Schlesinger did little to make the conclusion of the SALT II agreement with the Soviets any easier.

\section{The American Reaction}

The dismissal of Secretary Schlesinger created a storm of protest from both the political right and left in this country. The right 
regarded the firing as a mistake because they feared that Kissinger was neglecting the changes made in the international balance of power due to increases in Soviet strategic and military weaponry. The political left that Kissinger would becone even nore powerful and tend to embark on even more solo: perfomances in the conduct of American foreign policy, at the neglect of the powers of the Congress. The President was subjected to vast amounts of criticism in his handling of the Kissinger-Schlesinger feud that left same observers wondering as to the effectiveness of his leadership. 21 The study of the substantive differences and animosity between Kissinger and Schlesinger should show, however, that the President could no longer tolerate this situation and made the correct decision.

Both liberals and conservatives, doves and hawks, while disagreeing on Schlesinger's basic assumptions about American national security policy, did agree that the Schlesinger removal marked a victory for Secretary of State Kissinger. In spite of Kissinger's removal as National Security Advisor to the President, it was agreed that the Schlesinger firing placed Kissinger in a role in which he would be even more dominant in the direction of American foreign policy. Conservatives feared that the President would be kept insulated from the counter arguments that Schlesinger had raised. 22 Ifiberals feared a Kissinger hegemony over foreign policy and expressed the doubt that the Soviets

21) The Washington Post, November 5, 1975, p. 26

22) George F. Will, "Capital Issues", National Review, November 21, 1975, p. 1287 
and the United States would now reach a SALT II agreement. 23

The Ford Administration was severly criticized on Capital Hill for the Schlesinger firing. Democratic Senator Henry $M_{0}$ Jackson of Washington expressed the opinion that the Ford decision showed that the President "could not tolerate differences of opinion". 24 Congressional opponents of Kissinger were rellieved that he was no longer National Security Council Advisor to the President, 25 but many Congressmen thought that it was Kissinger, and not Schlesinger, who was the man that should have been removed. 26 Congressional Republicans were worried that the Schlesinger flring would hurt the President politically, especially with the conservative wing of the party that was anxious to follow the lead of former California Governor Ronald Reagan and take the Republican Presidential nomination away from the incumbent President. 27

The Kissinger-Schlesinger controversy had digressed far beyond the point of mere "differences of opinion". The fact that each Secretary had a different perception of detente and the means to preserve it had led to a schism in the Ford Administration that had become so intense that antagonisms between the State and Defense Departments carne out into the open and hurt the cohesireness of the administration's national

23) Tad Szulc, "The Firings and Foreign Policy", The New Republic, November 15, 1975, p. 8

24) George Lardiner, Jro, "Ford Fires Schlesinger, Colby", The Washington Post, November 3, 1975, p. 1

25) The Oregon Journal, Novenber 3, 1975, p. 7

26) The Iondon Times, November 4, 1975, p. 5

27) Rowland Evans and Robert Novak, Miscalculating at the White House", The Washington Post, November 5, 1975, p. 26 
security policy. Accusations by the State Department that the release of the DIA report to the American Security Council endangered detente is not samething that is charged because of a President's ambitions. The accusations by the Pentagon that Secretary Schlesinger's removal was the end result of a State Department campaign to weaken Schlesinger's inflaence is not scmething that can be attributed to election year politics, the incompetency of the President or the fact that Kissinger held down two jobs. The system of compromise and concensus building had completely broken dom.

Policy differences generated out of two entirely different viewpoints on detente and America's national security requirements were the principal reasons for the Kissinger-Schlesinger schism. The friction that evolved between Kissinger and Schlesinger over detente and American negotiating strategy gave President Ford no other alternative but to put an end to the struggle as soon as possible and suffer the political consequences of the decision. To do otherwise would have aggravated the division within his administration and perhaps have led to a serious policy confrontation in the future when the need for compromise and bargaining within the Administration would have been imperative. 


\section{Chapter IX}

KISSINGER AND SCHIESINGER: CONCLUSIONS AND COMMENTS

The Kissinger-Schlesinger controversy in the Ford Administration was developed out of theoretically different conceptions of the utility of power as a deterrent in the international system, the means by which the United States should come to policy decision on matters of national security, and the very role that the United States should play in the international system. These differences were so strong that a process of compromise in order to build a concensus on policy was made impossible in the Ford Administration. The fact that the decision making process in national security affairs is an inherently political one, with values and beliefs playing a major role in the process, should lead one to the conclusion that the reason for the split between Kissinger and Schlesinger had to be because of their value orientations and belief systems, rather than any other consideration. The refusal to compromise or bargain, through which a concensus can be denied, was due to individual differences in theory and philosophy that transcended any other consideration.

Differences on the nature of power, the rational and non-rational approaches to national security decision making and the dispute over whether the Soviet Union viewed detente in the same manner as the West were found to be the underlying reasons for the substantive policy disagreements on such issues as SALT negotiating strategy, possible Soviet violations of past agreements, U.S. defense spending and the importance of the growth of the Soviet military. The Kissinger model could be dew scribed as one that includes a belief in political multipolarity and the 
rationality of the decision maker. Kissinger's description of "revolutionary" and "legitimate" international systems are ones that helped to confirm in his mind the belief that the Soviets are now willing to pursue policies that show "an element of restraint". The fact that the Soviets, in the Kissinger model, had come to see that they could benefit from preserving the international system as it presently is influenced his belief that the United States must adopt a foreign policy that is limited in its objectives and a national security policy that takes into account the need to preserve the present detente relationship. Power and deterrence as elements of a U.S. national security policy are considered of less importance to Kissinger than to Dr. Schlesinger.

The Schlesinger model was found to stress a reliance on non-rational factors in the development of a national security decision making process. Deterrence, the personality of the decision maker and the importance of technological developments are all considered to be primary factors that should be considered in the determination of a national security policy. The assumed rationality of the decision maker and his need to seek peace was not as important as the perception of one's strength by other nations. Power was not considered in terms of its utility, but in terms of its deterrent effect. Schlesinger would agree that although it is of no utility for the United States and the Soviet Union to use nuclear weapons, it does not therefore mean that it is of no utility to have them. This is perhaps best demonstrated in Schlesinger's statement that detente is

1) James E. Dornan and Peter C. Hughes, "Power and Purpose in American Foreign Policy", Modern Age, Spring 1975, p. 173 
not gained independently of a general military and strategic equilibrium The fact that detente rests on an equilibrium of force, according to Schlesinger, is an "underlying requirement for the preservation of international political stability", and it is therefore important that the United States continue to maintain its commitments and strengthen its defenses in spite of detente. 2

The need to redefine the national security policy of the United States in an era of detente is the most important aspect in an analysis of the meaning of the Kissinger-Schlesinger dispute. Do deterrence and balance of power theories still matter in the age of detente? Does an increase in our capability to respond to potential nuclear threats enhance deterrence? Or does it increase the risk of nuclear war?

While Dr. Schlesinger believed that the balance of power and deterrence were requirements for the maintenance of international political stability, Dr. Kissinger does not share that belief. Kissinger has stated that,

"The shape of the future will ultimately depend on the convictions that far transcend the physical balance of power". ${ }^{3}$

Kissinger's approach is perhaps best described as one in which the Secretary wishes to present fewer opportunities to the superpowers and over nations for the use of nuclear weapons. Because nuclear warfare is almost always irrational, deterrence would be enhanced if fewer

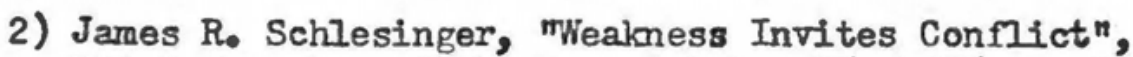
Vital Speeches of the Day, October 15, 1975, p. 2

3) Henry A. Kissinger, American Foreign Policy, (W. W. Norton \& Co.: New York, 1974) p. 80 
opportunites were available in whch a decision maker might attempt a nuclear war in hopes of gaining a temporary advantage. 4 Kissinger's writings and efforts as Secretary of State have been directed at trying to enhance deterrence through providing fewer opportunities for the utilization of nuclear weapons and through a nuclear policy that tries to negotiate force levels on the assumption that increases in nuclear force levels are a destabilizing influence on the strategic arms balance. The study of international politics must include the study of such concepts as power, the national security, peace and diplomacy. When differing opinions emerge over the meaning of these concepts, the problem is one of determining whether what are the political limitations of these concepts, and how a decision maker is to decide what is important and what is not important. At that moment, the factual evidence comes into play, and the decision maker must decide, upon the evidence that is before him, what policy to pursue. Kissinger and Schlesinger both observed evidences of changes in the military and strategic balance, changes in the composition of the international system, and changes in the attitudes of the American public on issues of foreign and national defense policy, and came to fundamentally different conclusions as to how our national security policy should be conducted.

The study of their individual belief systems, decision making models and perceptions are important in understanding why the substantive policy differences arose in the Ford Administration. If one was to Iook only at the substantive differences, he could conclude how the dispute

4) Herbert Scoville, Jr॰, "Flexdble Madness", Foreign Policy, Spring 1974, p. 164 
occurred, but he would have difficulty concluding why it occured. The study of the substantive policy differences on issues such as SAIT II negotiating strategy, detente with the Soviet Union, the size of the defense budget and possible Soviet violations of past agreenents show that each Secretary disagreed on fundrmental concepts in international politics such as power and the means by wich to come to national security decisions. Their differences became so intense that the Defense Department issued a study questioning the whole concept of detente.

The policy differences can be traced to the differences that each Secretary had of the international system, the role of power and deterrence, and the place of the decision maker in national security affairs. The administrative disharmony in the Ford Administration was the result of these differences. The President was forced to resolve the schism through the removal of one of the two antagonists. Foreign and defense policy coordination in his administration would have continued to deteriorate had he refused to do so.

The Kissinger-Schlesinger controversy in the Ford Administration has great significance if future administrations are to avoid reoccurrences of this situation. The coordination of defense and foreign policy is imperative in the present era of detente and nuclear parity. Above all the United States should heed the words of William P. Bundy when he wrote that the United States

\footnotetext{
"... should above all remain cool.. Refinements and continued research may be needed-- as I understand Secretary Schlesinger
} 
is now proposing - but in the last analysis the United States should refuse to be lured further into an unending arms race. $" 5$

The international system has undergone many changes in the years since the end of the Second World War. These changes were to cause Secretary of State Henry A. Kissinger and Secretary of Defense James Ro Schlesinger to disagree on major issues of national security policy in the administration of President Gerald R. Ford. The theoretical differences between the two Secretaries were manifested at the substantive policy level. This proves the thesis that it was the theoretical and conceptual differences on the nature of the international system, power in the nuclear age and the process by which to arrive at national security decisions in an age of detente that made compromise impossible within the Ford Administration on issues of national security.

5) William P. Bundy, "International Security Today", Foreign Affairs, October 1974, p. 28 


\section{BIBLTOGRAPHY}

\section{Books}

Brandon, Henry 1972. The Retreat of American Power, (Doubleday \& Co.: New York)

Deutsch, Karl 1968. The Analysis of International Relations, (Prentice $\mathrm{Hall}$ : Englewood Cliffs, New Jersey)

Graubard, Stephen Ro 1973. Kissinger: Portrait of a Mind,

(W. W. Norton \& Co. : New York)

Halperin, Morton H. 1974. Bureaucratic Politics and Foreign Policy, (The Brookings Institution: Washington, D.C.)

Hilsman, Roger 1971. The Politics of Policy Making in Defense and Foreign Affairs, (Harper and Row: New York)

Kalb, Marvin and Bernard Kalb 1974. Kissinger, (Iittle, Brown \& Co.: Boston)

Kissinger, Henry A. 1957. Nuclear Weapons and Foreign Policy, (Harper \& Bros.: New York)

$$
\begin{gathered}
\text { 1960. The Necessity of Choice, (Harper \& Bros.: } \\
\text { 1965. The Troubled Partnership, (NeGraw Hill: } \\
\text { New York) } \\
\text { 1974. American Foreign Policy, (W. W. Norton \& Co.: }
\end{gathered}
$$

Rosenau, James, (Ed.) 1969. International Politics and Foreign Policy, (The Free Press: New York)

Schlesinger, James R. 1960. The Political Economy of National Security, (Praeger: New York) 


\section{Articles}

Buchan, Alastair 1974. "The Irony of Kissinger", International Affairs, L, (July), 367-379.

Bundy, William P. 1974. "International Security Today", Foreign Affairs, IIII, (October), 24-4h.

Cleave, William Re and Roger Barnett 1974. "Strategic Adaptability", Orbis, XVIII, (Fall), 655-676.

Dornan, James E. and Peter C. Hughes 1975. "Power and Purpose in American Foreign Policy", Modern Age, XIX, (Spring), 167-179.

Girling, Jo Lo S. 1975. "Kissingerism: The Fnduring Problems", International Affairs, II, (July), 323-343.

Holsti, Ole 1962. "The Belief System and National Images", The Journal of Conflict Resolution, VI, 24h-252.

Kissinger, Henry A. 1966. "Domestic Structure and Foreign Policy", Daedulus, Ixxxxv, (Spring), 503-529.

1974. "Kaking Foreign Policy", Center Kagazine, VII, (January), 34-39.

1974. "The Washington Energy Conference: The American Challenge", Atlantic Community Quarterly, XII, (Spring), 22-30.

1974. "Address to the Sixth Special Session of the United Nations General Assembly", International Organization, XXVIII, (Summer), 573-583.

1975. "The Moral Foundations of Foreign Policy", Atlantic Community Quarterly, XIII, (Fall), 270-28I.

Kohl, Wilfred I. 1975. "The Nixon-Kissinger Foreign Policy System and U.S.-European Relations: Patterns of Policy Naking", World Politics, XXVII, (October), 1-43.

Nontgomery, John D. 1975. "The Education of Henry Kissinger", Journal of International Affairs, XXIX, (Spring), 49-62.

Noer, Thomas J. 1975. "Henry Kissinger's Philosophy of History", Modern Age, XIX, (Spring), 180-189. 
Newspapers and Periodicals

\section{Atlas (New York, N.I.)}

Aviation Week and Space Technology (Highstown, N.J.)

The Christian Science Monitor (Boston, Mass.)

Commentary (New York, N. $\mathrm{Y}_{\bullet}$ )

Commonweal (New York, N.Y.

The Congressional Quarterly (Washington, D.C.)

Current Digest of the Soviet Press (Washington, D.C.)

The Economist (Iondon, England)

Far East Economic Review (Hong Kong)

Fortune (Chicago, III.)

The German Tribune (Hamburg, West Germany)

The Japan Times (Tokyo, Japan)

The Iondon Times (Iondon, England)

National Review (Orange, Conn.)

Newsweek (New York, N.Y.)

The New Republic (Washington, D.C.)

The New York Times (New York, N.Y.)

The New York Times Magazine (New York, N. Y.)

The Oregon Joumal (Portland, Ore.)

Peking Review (Peking, Peoples Republic of China)

The Reader's Digest (Pleasantville, N.Y.)

Time (New York, N.Y.)

US News and World Report (Washington, D.C.)

The Washington Konthly (Washington, D.C.) 


\section{Documents}

"Flscal Year 1975 Authorization for Military Procurement, Research and Development, and Active Duty, Selected Reserve and Civilian Personnel Strengths", Hearings Before the Cormittee on Armed Services of the United States Senate, February 5, 1974, 93rd Congress, Second Session (U.S. Govermment Printing Office: Washington, D.C., 1974)

"Fiscal Year 1976 and July-September Transition Period Authorization for Military Procurement, Research and Development and Active Duty Selected Reserve and Civilian Personnel Strengths", Hearings Before The Committee on Amed Services of the United States Senate, February 5, 1975, 94th Congress, First Session, (U.S. Goverment Printing Office: Washington, D.C., 1975)

"The Nomination of Henry A. Kissinger to be Secretary of State", Hearings Before the Committee on Foreign Relations of the United States Senate, September 21, 1973, Part One, 93rd Congress, First Session, (U.S. Govermment Printing Office: Washington, D.C., 1973)

"The Nomination of James $\mathrm{R}_{0}$ Schlesinger to be Secretary of Defense", Hearings Before the Committee on Armed Services of the United States Senate, Jume 18, 1973, 93rd Congress, First Session, (U.S. Goverment Printing Office: Washington, D.C., 1973)

"Detente 1974", Hearings Before the Committee on Foreign Relations of the United States Senate, September 19, 1974, (U.S. Govermment Printing Office: Washington, D.C., 1973)

"Detente in Soviet Strategy", An Estimate by the Defense Intelligence Agency, Department of Defense, September 2, 1975 
PerImutter, Amos 1975. "Crisis Management: Kissinger's Middle East Negotiations", International Studies Quarterly, XIX,

(September), 316-343.

Quandt, Wil7iam B. 1975. "Kissinger and the Arab Israeli Disengagement Agreement", Journal of International Affairs, XXIX, (Spring), $33-48$.

Rathjens, G. W. 1974. "Flexible Response Options", Orbis, XVIII, (Fall), 677-688.

Safran, Nadar 1974. "The and the Future of the Arab-Israeli Conflict", Foreign Affairs, III, (January), 215-236.

Schlesinger, James R. 1973. "The Uses and Abuses of Analysis", reprinted in The Nomination of James $R_{0}$. Schlesinger to be Secretary of Defense, Hearings Before the Committee on Armed Services of the United States Senate, 93rd Congress, First Session, June 18, 1973, (U.S. Govermment Printing Office: Washington, D.C., 1973), 3-12.

1974. "The Strategic Consequences of Proliferation", Selected Papers on National Security: The RAND Paper Series \#5284, (September), 3-11.

1974. "Nuclear Spread: The Setting of the Problem", Selected Papers on National Security: The RAND Paper Series \#5284, (September), 12-22.

1974. "Arms Interaction and Arms Control", Selected Papers on National Security: The RAND Paper Series \#5284, (September), 23-32.

1974. "On Relating Non-technical Elements to Systems Studies", Selected Papers on National Security: The RAND Paper Series \#5284, (September) 76-91.

1975. "Weakness Invites Conflict", Vital Speeches of the Day, XIII, (October), 2-4.

Shlaim, Avi 1976. "The Failure of National Intelligence Estimates: The Case of the Yom Kippur War", World Politics, XXVIII, (April), $348-380$.

Stern, Laurence 1975. "Two Henrys Descending", Foreign Policy, XVIII, (Spring), 168-176.

Westervedt, Donald 1974. "The Essence of Armed Futility", Orbis, XVIII, ( $\mathrm{FaII}), 689-705$. 